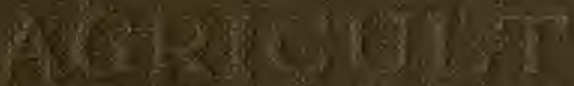

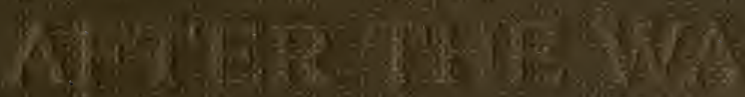

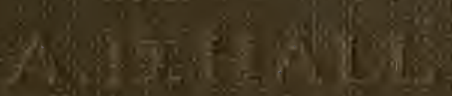

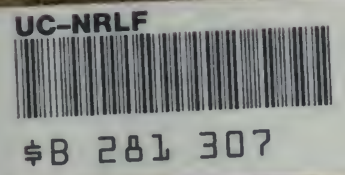



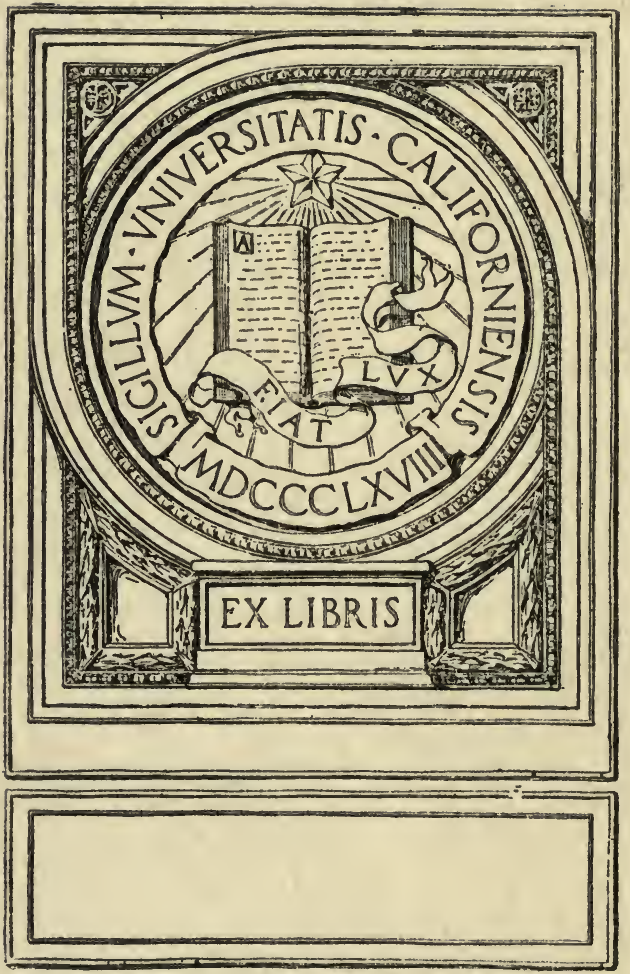


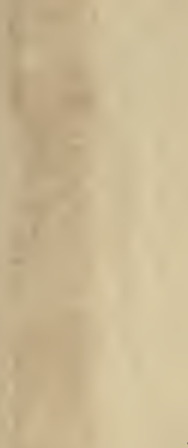

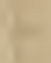

$-2=$

$=$

(n)

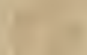

$+$ 
Digitized by the Internet Archive in 2007 with funding from Microsoft Corporation 
AGRICULTURE AFTER THE WAR 


\section{OTHER WORKS BY A. D. HALL, F.R.S.}

THE SOIL.

An Introduction to the Scientific Study of the Growth of Crops. 5s. net.

FERTILIZERS AND MANURES.

5s. net.

THE FEEDING OF CROPS AND STOCK.

An Introduction to the Science of the Nutrition of Plants and Animals. With Illustrations and Diagrams. 5s. net.

A PILGRIMAGE OF BRITISH FARMING, 1910-12. 5s. net.

THE BOOK OF THE ROTHAMSTED EXPERIMENTS.

Issued with the Authority of the Lawes Agricultural Trust Committee. With Illustrations. ros. 6d. net. 


\title{
AGRICULTURE AFTER THE WAR
}

\author{
By A. D. HALL, F.R.S.
}

NEW YORK :

E. P. DUTTON AND COMPANY.

1916 


$$
\begin{gathered}
H D 1927 \\
1916
\end{gathered}
$$




\section{PREFACE}

IT is not desirable that a servant of the State should publish his opinions on matters which are, or may be in the immediate future, the subject of political debate or legislative action. My excuse for what may be regarded as departing in some particulars from this wise rule is that the views here set out have, to a considerable extent, already been printed as evidence before one or other of the Departmental Committees appointed by the President of the Board of Agriculture and presided over by Lord Milner, Sir Harry Verney, and Mr. Henry Hobhouse. But as that evidence was necessarily given piecemeal and did not cover the whole ground, I have felt that I might be allowed to set out, in as coherent a form as I could give it, the whole case for the reorganization of agriculture in order to meet national needs and the situation created by the war.

The argument here presented may be imperfect, and the concrete proposals may be dismissed as impractical or replaced by others more expedient, but of the need for the adoption by the State of a considered agricultural policy for the better utilization of the land of the country I have no shadow of doubt. All that I hope to do is to provide materials for the due consideration of such a policy, and the best I can urge on behalf of my own opinions is that I have endeavoured to be fair and to give due weight to all the evidence available without special pleading with regard to any party or interest.

My text is the need for an increased production of food at home and the greater employment of men upon

$$
357950
$$


the land as essential to the security of the Nation as a whole, and independent of the particular interests of either landowners or farmers.

Some of my friends will consider that I have been unjust to the farmers of the country, and will refuse to accept my assurance that they are among the minority whose standard of work I desire to see universal. But I am not out to award either praise or blame; I want to arrive at the facts and ensure their examination from the point of view of the national needs. A man may be a first-rate farmer as regards his own personal success and yet be pursuing a policy inimical to the ultimate welfare of the State. Before one attaches any blame to the current race of farmers one must consider the extraordinary crisis through which they have passed in the last thirty years without any attention or assistance from the State, then one will be more inclined to praise them for having contrived to remain in existence at all.

I have to thank many friends for assistance in the preparation of these pages, either in the shape of information or of criticism. In particular I would wish to mention my colleague, Mr. Vaughan Nash, C.B., C.V.O., Professor W. G. S. Adams and Mr. C. S. Orwin of Oxford, Professor T. B. Wood and Mr. K. J. J. Mackenzie of Cambridge, Mr. C. W. Fielding, Mr. Harold Faber, Danish Commissioner, and Mr. S. Stagg of the Development Commission, who has given me great assistance in reviewing the statistical figures quoted.

\section{A. D. Hall.}

February, I9I6. 


\section{CONTENTS}

CHAPTER I

OUR DEPENDENCE UPON IMPORTED FOOD • - I

CHAPTER II

THE DECLINE OF BRITISH AGRICULTURE - - I8

CHAPTER III

ARABLE LAND VERSUS GRASS - - - - $\quad 29$

CHAPTER IV

POSSIBLE DEVELOPMENTS - - - - - - 39

CHAPTER V

THE CAPACITY OF THE LAND FOR FOOD PRODUCTION 85

CHAPTER VI

THE DEPENDENCE OF ARABLE FARMING UPON

PRICES - - $\quad$ - $\quad$ - $\quad$ - $\quad$ - $\quad$ - $\quad$ - $\quad$ - $\quad$ - 104

CHAPTER VII

WHAT ACTION IS PRACTICABLE - - - - - II8

CHAPTER VIII

SUMMARY AND CONCLUSION $\quad$ - $\quad$ - $\quad$ - $\quad$ - $\quad$ - 127

APPENDICES

I. AGRICULTURAL IMPORTS AND EXPORTS, I913 - 132

II. ACREAGE AND LIVE STOCK RETURNS, I870-I9I5 I34

III. AGRICULTURAL POPULATION OF ENGLAND

AND WALES, I87I-I9II - - - - - - 136

I V. CONSUMPTION OF FERTILIZERS IN THE U.K., I9I3 I37 



\section{Agriculture after the War}

CHAPTER I

OUR DEPENDENCE UPON IMPORTED FOOD

WHILE it is generally recognized that the United Kingdom occupies a unique position among nations in its dependence upon foreign countries for a large proportion of its food supplies, some of the consequences of that dependence are only just being brought home to us by the course of the present European war. The possibility of starvation or of such grave interruption to the ordinary course of our trade as to enforce our submission to our enemies has for the present been averted; but enough has been seen of the unanticipated developments of modern warfare and of the financial situation that it creates, to call for a review of our national policy with regard to food supply and the consideration of our agricultural position from a standpoint that has hitherto been neglected. It is not too much to say that the British people never really believed that they would be involved in a war of the present magnitude. Opinions may differ as to the adequacy or the wisdom of our naval and military preparations; but all would agree that no attempt had been made to foresee or to provide against 
the effect of war on the general life of the people and on the industrial and commercial situation upon which the existence of the nation ultimately depends. The strength that Germany has shown, her capacity to maintain the offensive even when cut off from the mass of her foreign trade, have not been wholly due to her natural resources, but have, in the main, been brought about by deliberate prevision of the conditions that war would create and by the preparation of the whole fabric of the community for the shock, in which preparedness the position of agriculture and the question of food supplies have been matters of prime importance. So it must become for us; whether we like it or not the possibilities of war have definitely re-entered our scheme of existence, and the consequences of war will depend upon the clearness and forethought with which we prepare for it in our social organization. The question of our dependence upon foreign supplies is not solely a matter of whether we can get the food necessary to maintain our population, though submarine warfare has developed so rapidly that we must be prepared for a much more effective blockade of the British Islands that will only allow a few food ships to slip through. Even the course of the present war has shown us how narrow the margin of safety may become; in May, I9I5, the price of English wheat rose to $68 \mathrm{~s}$. per quarter ; in February, Igr6, it is already as high as 63s., very largely because of the wholesale withdrawal of freight for war purposes. A little further destruction of shipping or increase of danger to cargoes afloat and the price might rise to a level that would so disturb the internal economy of the nation as to hamper it grievously in the prosecution of the war. 


\section{MAGNITUDE OF IMPORTS}

Moreover, the prime business of the Navy is to fight, and the intensification of the attack upon our commerce that we may reasonably anticipate in any future war, would necessitate such a withdrawal of our ships in order to guard the trade routes as would dangerously weaken the offensive powers of the Navy. Thus the great dependence of the country upon foreign food supplies renders us liable to internal disturbances created by high prices even when starvation is out of the question; it adds to naval expenditure because of the prime necessity of securing the entry of shipping, and therefore embarrasses and weakens the action of the Navy at a time when its whole strength ought to be free to concentrate against the enemy.

Weighty as are these considerations, even more serious is the financial instability that is created in war time by our absolute dependence upon a large volume of imports. The nation's position as regards imports may be summarized as follows:

TABLE I.

\begin{tabular}{ll|cc|cc}
\hline & & Total Imports. & $\begin{array}{c}\text { From British } \\
\text { Possessions. }\end{array}$ \\
\hline Food, drink, and tobacco & $£ 290$ millions & $£ 76$ millions \\
Raw materials .. &.. & 282 &, & 92 &,, \\
Manufactured articles &.. & I94 &, & 23 &,, \\
\hline
\end{tabular}


Taking the "food, drink and tobacco" imports in detail, and excluding the materials that are not produced in the United Kingdom-maize, oranges, bananas, sugar, tea, wine, etc.-we import of food materials :

Wheat and other grains $\quad \ldots \quad \ldots \quad £ 68$ millions

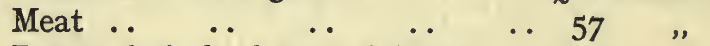

Butter, fruit, lard, eggs, fish, etc. .. $7 \mathrm{I} \quad$ "

to which might be added $£$ I4 millions for maize that we may regard as replaceable by cattle food grown in this country, and a further $£ 44$ millions for wool and hides, which are equally agricultural products natural to our soil. Our imports of agricultural materials which are also in part produced in this country thus amount to $£ 242$ millions (less $£ 46$ miliions for reexports), of which British Possessions send only for millions.

Considering food proper the imports, less the reexports, amount to about $£ 229$ millions per annum, of which only $£ 62$ millions are drawn from British Possessions, leaving an annual adverse balance against the Empire of $£ \mathrm{I} 67$ millions. This is a bill for material that is consumed in the country and does not go out again in a manufactured form, as do imports of other raw materials ; more particularly in this connection it is a bill for materials we cannot dispense with in war time. Under peace conditions we pay for our imports of food and raw materials by our exports, i.e., by the labour put into the conversion of raw materials into finished goods, e.g., cotton goods and machinery, or by raw materials of our 
own, e.g., coal, or by our foreign investments. A European war like the present considerably reduces our manufacturing for export,* but though we can cut off automatically the imports required for that purpose we cannot cut off the food nor the increasing volume of materials that are wanted for war purposes. In war, the balance of trade must go against the nation : exports cease to pay for imports, which have to be bought upon credit, and that credit becomes the more strained the bigger the import bill. In the case of the United Kingdom we have to continue depreciating the imperial credit by buying from outside the Empire 167 million pounds worth of food, the whole or any part of which, if produced at home, would not lower the national credit at all during the war, because it would be paid for in paper at home where the credit of that paper is unassailable. It may be more profitable in peace time to buy food and pay in manufactures, but when war comes and we can neither make nor sell the finished articles though the food bill has still to be incurred, then so large an annual debit as $£ \mathrm{I} 67$ millions becomes

* The falling off in exports during war may be estimated from the following figures. (Accounts relating to Trade and Navigation, Dec., I915.)

\begin{tabular}{|cc|c|c|}
\hline Exports. & I9I3. & I9I 5. \\
\cline { 3 - 4 } Coal and coke & $\ldots$ & $£$ (millions.) & $£$ (millions.) \\
Iron and steel & $\ldots$ & 53.7 & 38.8 \\
Machinery.. & $\ldots$ & 37.0 & 40.4 \\
Cotton goods & $\ldots$ & I27.2 & 85.2 \\
Woollen goods & $\ldots$ & 37.7 & 32.9 \\
\hline Total exports &.. & 525.0 & 385.0 \\
\hline
\end{tabular}




\section{INCREASED COST OF IMPORTS DURING WAR}

a serious item in depreciating the Empire's credit. The consumer also is doubly hit in the price he has to pay at home; he pays more because of the fall in the Exchange; he pays far more because of the freight difficulty a general war creates, and of the magnitude of that difficulty we had no conception before this war began. The following comparison (Table II) of the quantities and values of the more important articles of food, for the years I9I3 and I9I5, shows the enormous extra cost of food in war time:

TABLE II.-QUANTITIES AND VALUE OF CERTAIN IMPORTS OF FOOD, IgI3 AND I9I5

(Accounts relating to Trade and Navigation, Dec., I9I5)

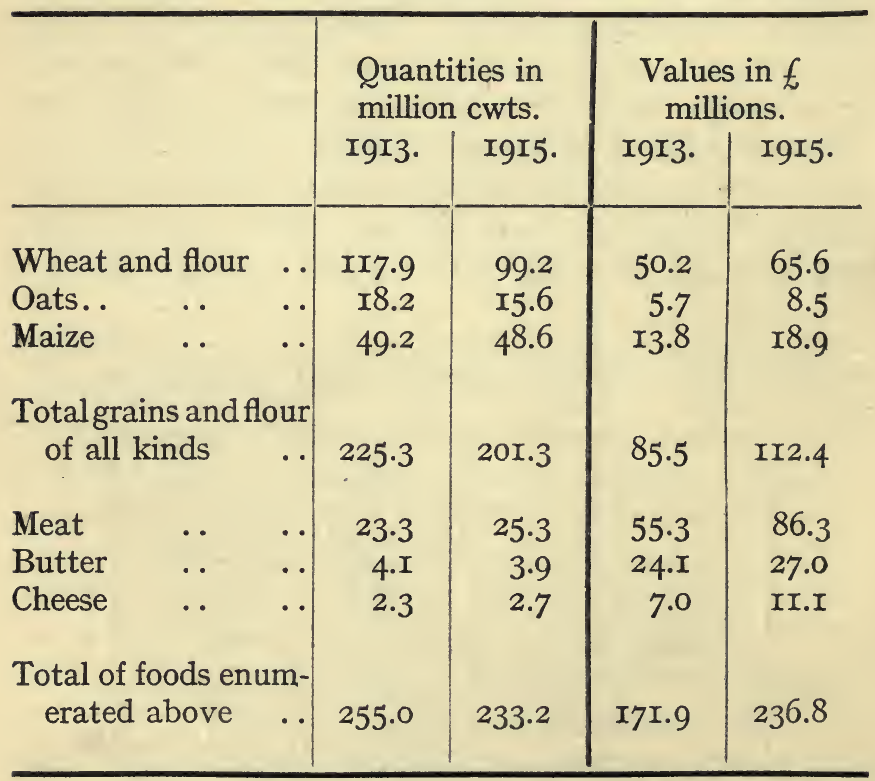


Thus of the main articles of food selected for comparison (the value of which was $£$ I 72 millions in I9I 3 out of a total of $£ 255$ millions) the quantity imported fell in I9I5, the war year, by 22 million cwts. or 9 per cent. ; but the cost to the country rose by $£ 65$ millions, or 38 per cent. Various articles have been omitted from this comparison because of the difficulty of bringing the quantities into line-e.g., eggs-or because the imports could not be replaced at home-e.g., sugar-but if we consider values alone the $£ 290$ millions paid for food, drink and tobacco in I9I3 became $£ 382$ millions in I9I5, an increase of 32 per cent. in cost for a smaller quancity of goods. A greater home production of food would relieve both the foreign Exchange and the freight market, which as we have learnt to our cost becomes in war time preoccupied with the movement and supply of troops and the carriage of materials indispensable for munitions.

The burden of the food bill and the extent of our dependence upon foreign supplies falls into better perspective if we consider it in connection with the domestic production. Estimates of the amount of food grown in the United Kingdom can only be very approximate; the best data available are those contained in the Census of Production for Igo8 (see The Agricultural Output of Great Britain and The Agricultural Output of Ireland, I9I2), which may, without much error, be set alongside imports for I9I3 because no change has intervened to vitiate the general comparison. The following table, No. III, gives for the main articles of human food a comparison of the imports from foreign countries and British Possessions with the estimated production for sale in the British Islands. 
TABLE III.-COMPARISON OF IMPORTS FROM FOREIGN COUNTRIES AND BRITISH POSSESSIONS WITH PRODUCTION IN THE UNITED KINGDOM. VALUES IN MILLION $£$. IMPORTS FROM ANNUAL STATEMENT (CD. 7968): UNITED KINGDOM PRODUCTION FROM AGRICULTURAL OUTPUT OF GREAT BRITAIN AND IRELAND FOR I908:

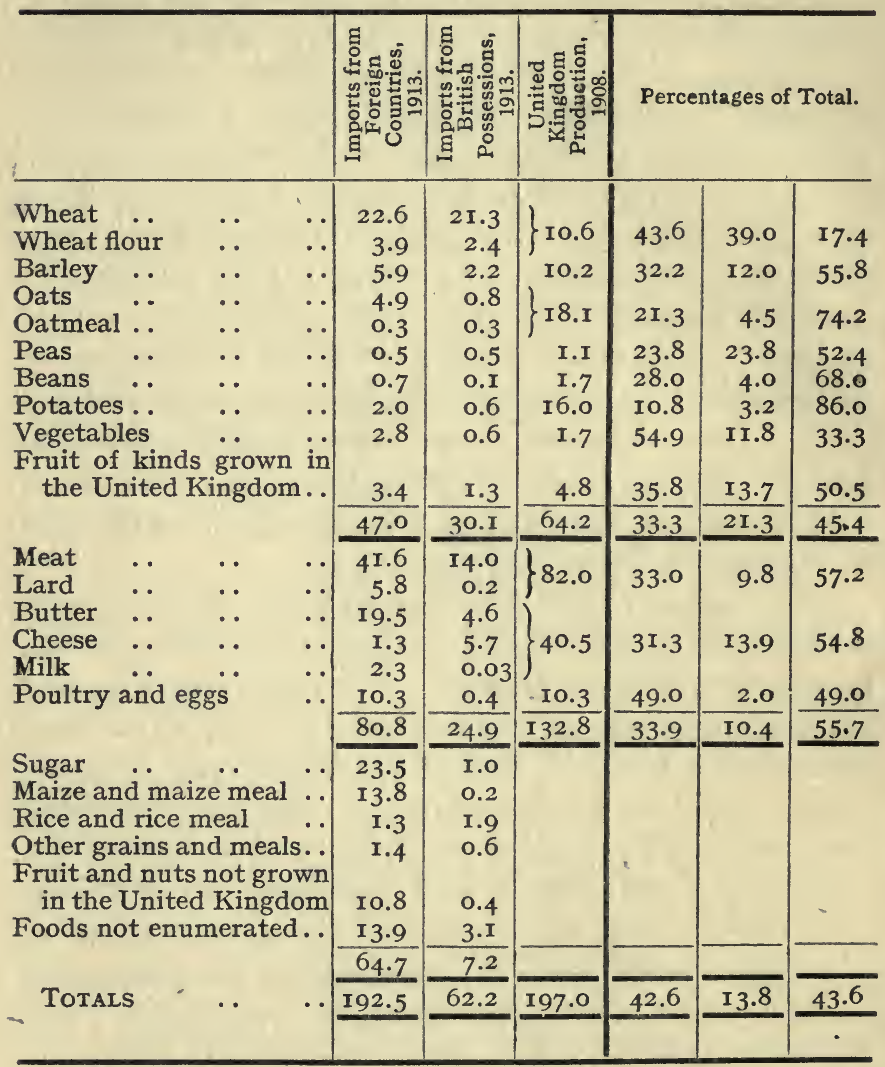

It has been necessary to express the comparison in values, as the relative quantities are not always available $-e . g$. , though the weight of imports of meat is known the home production has to be estimated in numbers of animals. The consideration of values leads to certain 


\section{RA'TIO OF IMPORTS TO HOME PRODUCTION 9}

Of wheat and wheat flour the home production amounts to a little more than one-sixth of the total consumption if we consider values, one-fifth when quantities are compared. Thirty-seven per cent. of the whole consumption and nearly one-half of the total imports come from British Possessions-India, Canada, Australia.

Of the other corn grown in this country-barley, oats, peas and beans-the importations are less than one-half of the home production and they are chiefly from foreign countries. Of potatoes the importations amount to about $£^{2 \frac{1}{2}}$ million yearly, the bulk coming from foreign countries; but this is only a small fraction in value and a still smaller fraction in quantity of the domestic consumption, which is much larger than the figure set down because that takes account only of the potatoes grown for sale on the field scale and not of the produce of the small holaings, allotments and private gardens. The same qualification has to be applied to the consideration of the output of vegetables; the importations to the value of $£ 3.4$ millions amount to double the estimated home production, but the latter figure only represents the sales of such market gardeners as are working on a large enough scale to be able to make returns to the Board of Agriculture of the acreage they have under the various crops. What the actual output for consumption is would be difficult to estimate; but for the present purpose it is evident that there is a comparatively considerable importation,

elements of error-e.g., in dealing with potatoes the value of the imports is disproportionate to the quantity because a large proportion consists of early potatoes commanding a special price. But allowing for these imperfections in the comparison, the main purport of the table is clear enough. 
$£ 2.8$ millions from foreign sources, which might in part be replaced by home-grown produce. To sum up the part of the table that is concerned with food materials of vegetable originwhich are produced also in the United Kingdom, the importations amount to $£ 77$ millions against a home production (admittedly under-estimated) of $£ 64$ millions, and of the importations less than half ( $f 30$ millions) come from countries within the Empire.

With regard to animal products, the importations of meat and lard amount to over $£ 60$ millions annually ( $\mathrm{I}$ 4 millions, or 23 per cent., from British Possessions), against which we have to set an estimated home production of $£ 82$ millions. This latter estimate is subject to two errors : in the first place it represents the value of animals on the hoof as sold by the farmer, whereas the imports are dressed carcasses ready for sale, i.e., meat alone. However, we may take, as a rough rule, that the value for sale of the meat in an animal is about equal to seven-eighths of the price received by the farmer. But if the value of the home-grown meat is thus reduced to less than $£ 74$ millions, something should be added to the home production for hides and skins, tallow, etc.

On the other hand, though the farmer's output is estimated at the value of $£ 82$ millions, this is too high a figure for the value of the meat that reaches the consumer, because the Irish output has been reckoned like the British, as animals ready for slaughter. A large proportion of the Irish trade is in animals in store condition, that are bought by British farmers to be finished, and so become reckoned twice over in the British as well as in the Irish production. It has been estimated that a deduction of about $\frac{f}{\sim} 7$ millions ought 
to be made on this account, bringing the value of the

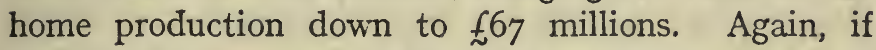
we wish to compare quantities, we must make allowance for the fact that home-grown meat is sold at a higher price than foreign; a dediction of one-seventh can be made on this account. However, the general conclusion remains that we produce at home considerably more than half of our normal consumption of meat, and of the total imports rather less than one-quarter comes from British Possessions. Thus the situation as regards meat is safe enough. Three-quarters of our supplies originate within the Empire, and in a time of real stress the consumption could be diminished in this ratio without harm to the community, while the breeding stocks, equal to at least a year and a half's normal consumption, form an ultimate reserve in case of an absolute blockade.

The figure given for dairy produce originating in the United Kingdom is for various reasons a very doubtful one. In the first place the estimate of the amount of milk produced has to be founded only upon the recorded number of milch cows, and the value to be attached to that milk can only be roughly guessed at, for that which is sold as milk by the British farmer obtains nearly double the price of that which the Irish farmer has to sell in the form of butter. The whole fresh milk consumption is supplied by the home producer; but approximately the cost of the imports of dairy produce (one-third of which come from British Possessions) amounts to about 40 per cent. of the total expenditure of the nation on milk, cheese and butter, though the nutritive value of the imports would be more nearly equal to that of the home produce. Fggs and 


\section{I2 IMPORTS AND HOME PRODUCTION}

poultry are imported to the value of $£$ ro.7 millions, of which only a very small fraction comes from British Possessions. The value of the home production is estimated at $£$ Io.3 millions, a figure which again takes no account of the large amounts which are consumed by private producers and are never sold. On the whole, we may estimate that at least one-half of the total consumption is grown within the United Kingdom.

In addition we consume about $£ 40$ millions worth of food-sugar, rice, nuts and fruit-that is not produced at all in the United Kingdom, and only about $£ 3$ millions of this comes from British Possessions.

TABLE IV.-COMPARISON OF IMPORTS AND HOME PRODUCTION (I9IO-I4)

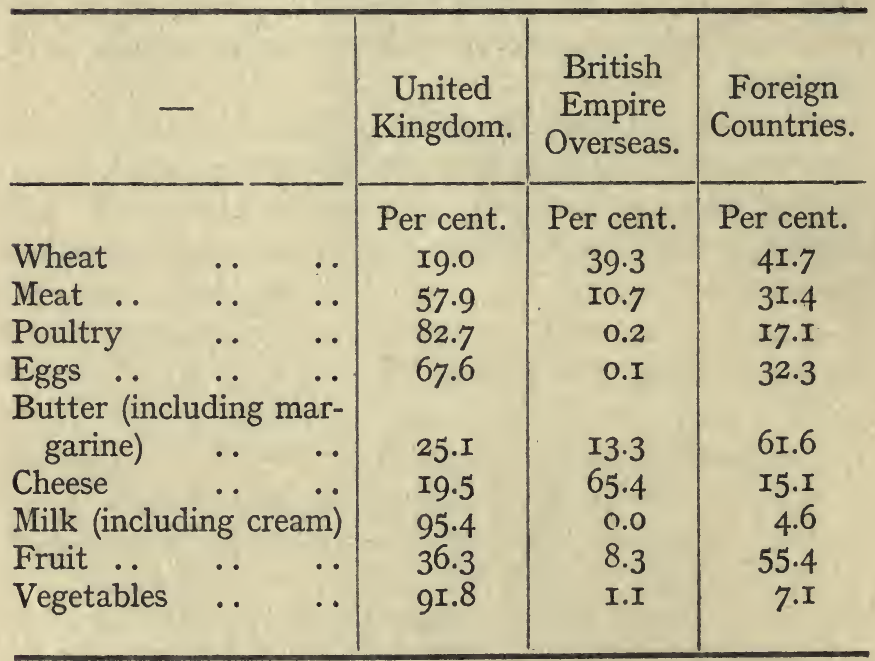

Mr. Rew's estimates for the five years I9I0-I4 (Journal of the Board of Agriculture, XXII, I9I5, p. 5I4), 
are set out in Table IV. It is not stated whether the comparison is for values or quantities, but the results agree substantially with the single year's figures already discussed.

Summarizing, of these major articles of human food we have a home production to the value of about $£$ Igo millions against an importation to the value of $£ 220$ millions, $£ 60$ millions of which come from British Possessions. Of meat, dairy produce, potatoes, etc., we produce one-half or more of our consumption ; the really weak spot is the fundamental foodstuff-wheat, of which we only produce at home one-fifth of our requirements.

We arrive, then, at the following conclusions: the British Islands are importing about one-half of the total food they consume if reckoned in values but considerably more than one-half if the efficiency of the food in maintaining life and work is considered. The payments for this food and other agricultural material producible here amount to over $£ 250$ millions per annum, of which two-thirds are paid to foreign countries not within the British Empire. In war time this importation constitutes a source of weakness to the nation in three directions:

I. Through the absolute danger of starvation, or of such a limitation of supplies as will raise prices to the point of creating an internal crisis.

2. By the withdrawal of our naval power from its offensive function to that of guarding the trade routes. 


\section{I4 THE COST OF NATIONAL SECURITY}

3. Through the reduction of the national credit by the necessity of paying such large amounts, which are materially increased in war time, to foreign producers.

In our national policy we have hitherto tacitly accepted these dangers; we have worked upon the assumption that it is better for the British Islands to develop as an industrial and trading community, exchanging the elaborated products of our manufacturing skill for the more primitive articles of food and raw materials, because we thus turned to better profit the labour of our dense population. We have trusted to the Navy to protect the transit of the necessary food, and in that expectation we have not been deceived; but we have not foreseen that the physical power to continue importations is only one, and not perhaps the most important, part of the problem of national security; the further financial question of the continued ability of the nation to pay for such food during a long war has only now been brought home to us.

We are thereby forced to ask ourselves whether a review of this national policy has not become necessary -a review that will take war and its revealed consequences into account and will so reshape the agricultural system of the country as to remove or reduce materially the dangers that arise from our great dependence upon foreign supplies of food. If it is possible to produce the bulk of our requirements at home we shall thereby effect a further insurance of the safety of the nation-an insurance that is additional to and independent of the Navy, which assists the Navy in its 
proper task, and which adds to the financial stability of the nation in a manner the Navy cannot do.

It is no final answer to the proposition submitted for consideration to say that experience has proved that it is cheaper for a nation in our position to buy its food in the open market and pay for it with manufactures. All questions of cheapness are relative. It would be cheaper to dispense with the Navy and Army if we could ensure peace ; but as that is impossible we accept the burden of maintaining the Services, and the question we have to consider is whether an enhanced agricultural output, such as can be attained at some price or other, may not be a part of the national defence so necessary that it has to be paid for, cheaply or otherwise. The answer turns on the degree of necessity and the degree of cheapness, for we have learnt that the market may not be always open and will become a very dear one just at the time when it is most imperative to confine our expenditure within our own dominions.

Moreover, there is a social side to the question-that of the effect of their occupation upon the character of our people. A population dependent entirely upon manufactures gives rise to an unstable State, subject to comparatively violent fluctuations of employment from causes which are liable to affect all industries simultaneously ; an agricultural community alongside the industrial one serves as a reservoir for labour, absorbing the fluctuations because its own variations depend upon different factors, and so equalizing the demand. Politically a country population is the more sober and cautious because it is in touch with certain fundamental aspects of existence that are hidden away from the purely town dwellers. No one concerned with the ulti- 
mate welfare of our nation can view with equanimity the tendencies of the last half-century, the continuous depopulation of the country and the growth of the towns. If the process continued our State would become economically parasitic upon the more primitive foodproducing countries; and a parasite, however highly organized, cannot continue to exist if the connection with its host is severed.

To attempt the adjustment of the future occupations of our population may appear too remote an enterprise and one too liable to disturbance by unforeseen factors to be contemplated; but there is before us the immediate practical question of the employment of our returned soldiers at the close of the war. We must be prepared for a great industrial depression following the war, even though there may be a temporary demand for labour for reconstructive purposes. Still, the enormous destruction that has been wrought and the burden of taxation that will be resting on all European countries must cause all industries to languish, especially those producing articles which are not universal necessaries of life. In consequence many of the men returned from service will find no places open in the industries they have left, even allowing for the vacancies created by deaths and disablement, and this shortage of employment will be intensified by the considerable replacement of men by women that is daily going on. The men themselves will, in many cases, be seeking an outdoor life; the routine of their occupation in the factory or the office has been broken; some of them will have acquired an antipathy against the monotony of manufacturing or commercial wage earning, and will look for employment 
upon the land. If that feeling cannot be satisfied at home they will take the first opportunity of emigration to countries where land is obtainable, urged thereto, moreover, by the pressure of taxation that will then be resting upon this country. Here, indeed, lies one of the gravest dangers to the future of the United Kingdomthat just when we need increased production to pay for the expenditure incurred in the war we may lose by emigration a large proportion of the most active and enterprising of our population, and thus increase the burden upon those who remain. In order to avoid depopulation of a cumulative and disastrous type, the State must exert itself to provide fresh outlets for employment, and the land presents the most fruitful opportunity. Nothing will better meet the exigencies of the situation than a more intensive employment of the land; it is a comparatively undeveloped national asset, and its utilization will menace no existing industry but will result in the direct production by labour alone of real wealth from our existing resources. It will also be production of the most necessary of all materials, the demand for which springs from the fundamental needs of the community and does not depend on the possession of a margin for superfluities. After the war many classes of the community will be impoverished by taxation and their power of making purchases abroad will be correspondingly reduced; the nation as a whole will have to work harder and to depend as much as possible upon its own internal resources, of which the land has been the least exploited. 


\section{CHAPTER II}

THE DECLINE OF BRITISH AGRICULTURE

Ir is necessary to elaborate this latter propositionthat the land of the British Isles is capable of much greater production than is at present obtained, and that, too, at a cost which is profitable to the community as a whole. The history of British agriculture for the last forty years has been one of continuous decline from the point of view of the gross production from British soil, and without considering the advances made by individual farmers or the progress in particular directions, such as fruit-growing and market-gardening. The changes are perhaps most easily followed when expressed graphically, accordingly Fig. I has been drawn to show for England, Wales and Scotland, the total cultivated area and the area under arable farming for the period I870 to I9I4. In Fig. 2 the numbers of milch cows, other cattle, and sheep are shown for the same peiiod, together with a curve indicating the average price of beef and mutton. Finally, in Fig. 3, the various curves provide a comparison of the arable area in England and Wales with the population engaged in agriculture, and the rate of wages with the estimated average cash return from an acre of arable land for the same period, I870-I9I4. 
CULTIVATED AND ARABLE AREAS I9

FIG. I.

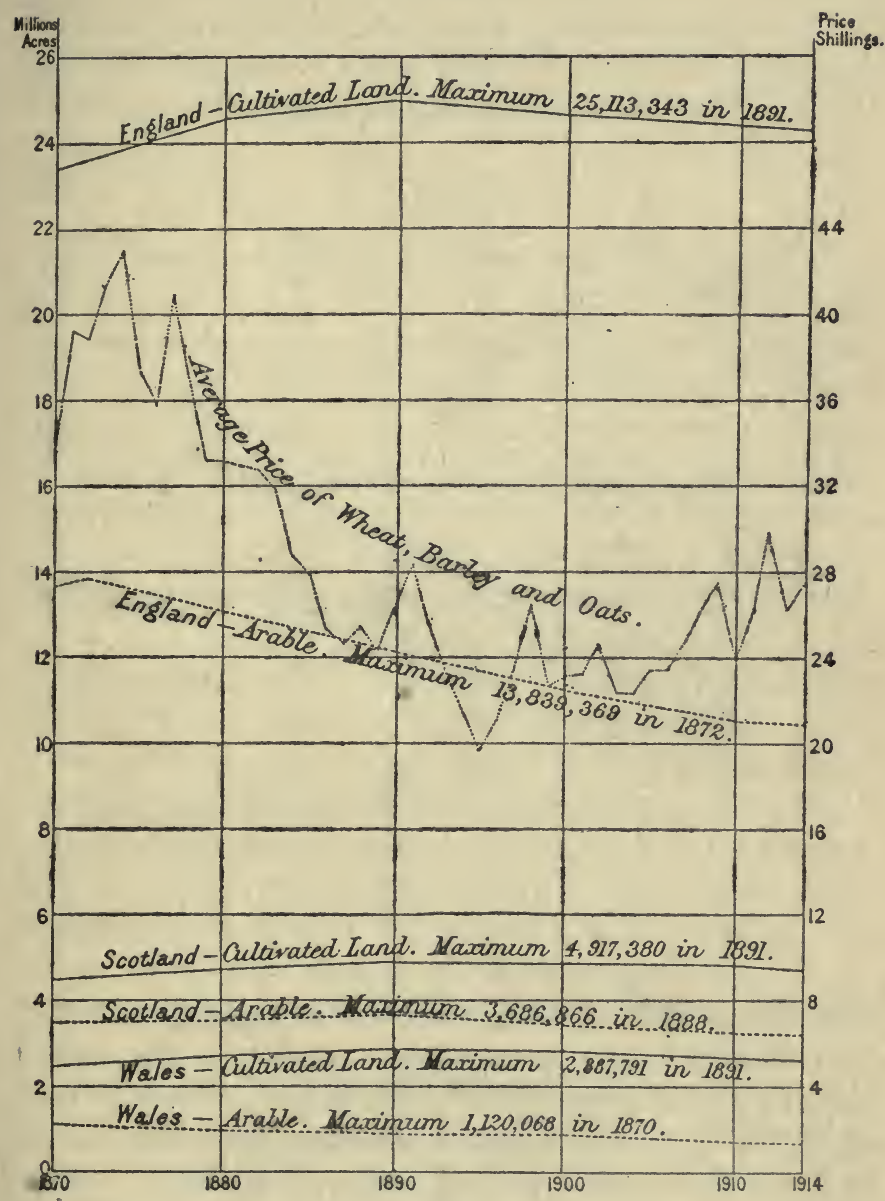




\section{DECLINE OF BRITISH AGRICULTURE}

It will be seen that the total cultivated area-crops and grass-has changed but little. There was some rise in the early 'nineties; since that time there has been a small decrease, due in the main to agricultural land being taken for various urban purposes, industrial

\section{FIG. 2 .}

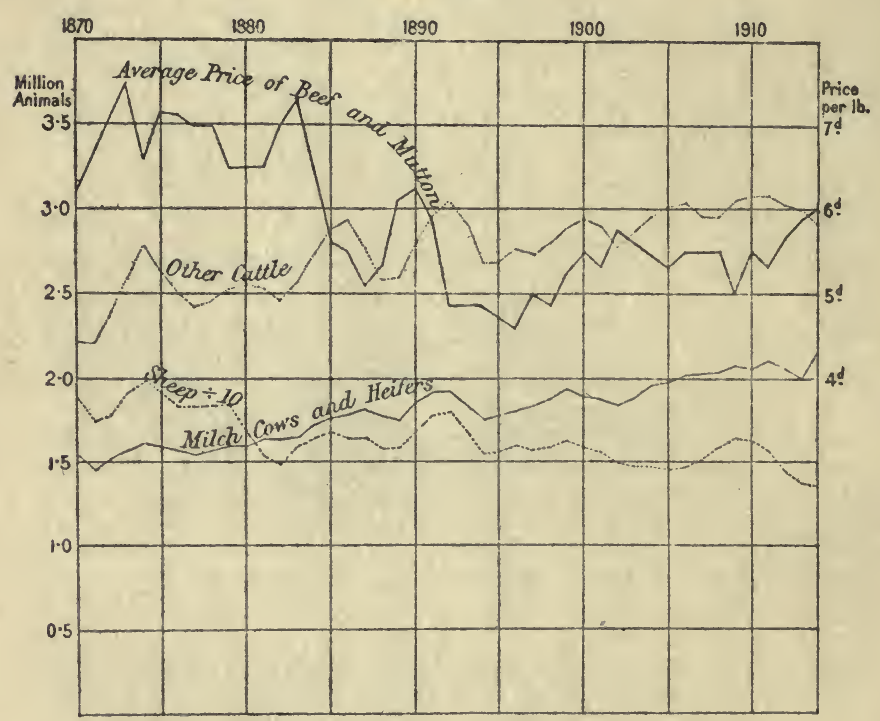

and residential. Latterly there has been no attempt to deal with the considerable area of waste land that lies on the margin of cultivation; the processes of reclamation that had been steadily going on up to 1892 then ceased in England, and owners have not invested capital in any further winning of unused land for cultivation. 


\section{LOSS OF ARABLE LAND}

The most marked change has been the steady conversion of arable land into grass. In England

FIG. 3 .

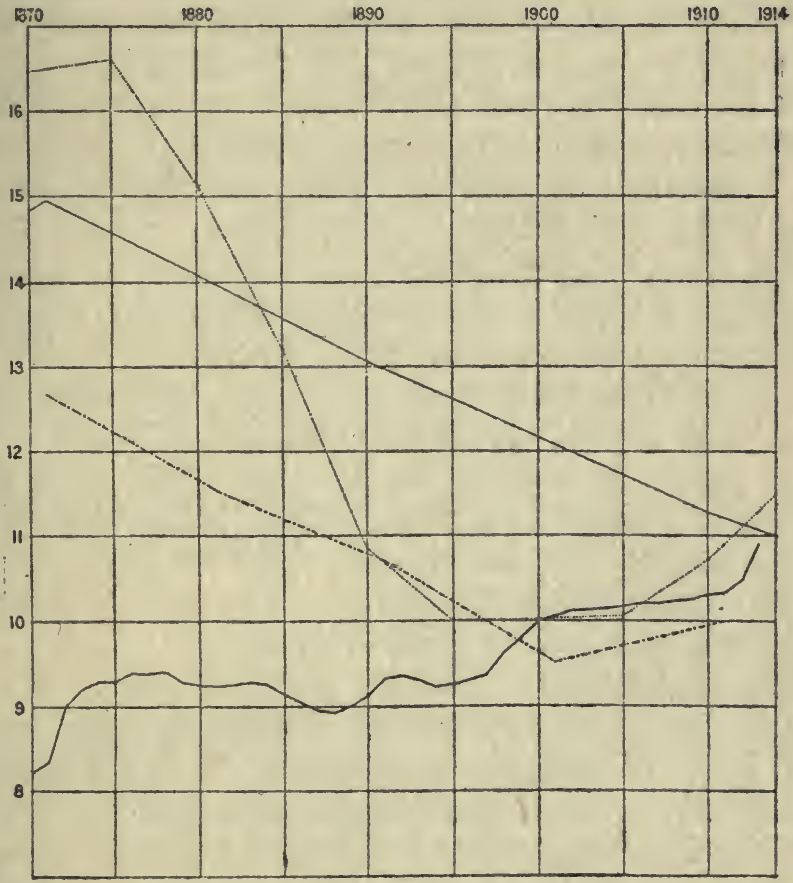

Returns per acre of arable land (average for five years) in tens of shillings.

Area of arable land in million acres.

Number of persons engaged in agriculture in hundred thousands.

Average weekly cash wages compared with wages in 1900 , when the average wage was $15 \mathrm{~s}$., equivalent to about 18s. total earnings. Each division of the scale above or below $10=1 \mathrm{~s} .6 \mathrm{~d}$. above or below 15s.

and Wales the area under the plough reached its maximum, I3,839,369 acres, in 1872 ; by I9I4 it had 


\section{DECLINE OF BRITISH AGRICULTURE}

fallen to $10,306,467$ acres-a loss of 26 per cent. This process was undoubtedly brought about in the earlier part of the period by the great fall in prices which set in during the later 'seventies and 'eighties. Arable farming as then practised ceased to be remunerative on the heavier and poorer soils; meat and milk maintained their values better; so that the only way open to the farmer to obtain a profit was to reduce his labour bill and to take the small but comparatively certain return that the land would yield under grass. Naturally, the process went on unequally in different parts of the country; the arable farming was chiefly maintained in the East, where the rainfalls: are light, thus rendering the grass less remunerative, and where operations of cultivation and harvest are least interfered with by the weather. Still, even the Eastern Counties like Essex, where heavy clay soils predominate, were largely laid down to grass, while areas of light soil in the West, such as parts of Shropshire, continued their arable farming.

The change from arable to grass has been accompanied by an increase in the number of cattle kept but by a decrease in the number of sheep, which, in English agriculture, are for the main part associated with arable farming and fed upon green crops grown on the plough land. With the loss of the arable acreage the gross output of food has declined, more in quantity than in value, because corn has been replaced by meat and milk of which the fall in price has been less pronounced. In Table V. a comparison is made between the output of I9I3 and that of 1872 , assuming the prices of 1908 (see Table III) and the same yields per acre and production from a given head of stock in 
the two years. Only wheat, barley, potatoes, milk and milk products, meat and wool are supposed to be sold, the other crops being consumed in feeding the stock.

TABLE V.-AiGRICULTURAL OUTPUT OF ENGLAND AND WALES, I872 AND I9I3

\begin{tabular}{|c|c|c|c|c|c|}
\hline \multirow{2}{*}{\multicolumn{2}{|c|}{1}} & \multirow{2}{*}{$\begin{array}{c}\text { I872. } \\
\text { Thous'd } \\
\text { acres. }\end{array}$} & \multirow{2}{*}{$\begin{array}{l}\text { IgI3. } \\
\text { Thous'd } \\
\text { acres. }\end{array}$} & \multicolumn{2}{|c|}{$\begin{array}{l}\text { Total Value of } \\
\text { Produce. } \\
\text { f millions. }\end{array}$} \\
\hline & & & & I872. & I9I3. \\
\hline Wheat & . & 3,463 & $\mathrm{I}, 702$ & 22.07 & I0.85 \\
\hline Barley & - & 2,064 & I,559 & II. 37 & 8.59 \\
\hline Potatoes & & 387 & 442 & 6.66 & 7.60 \\
\hline \multirow{6}{*}{$\begin{array}{l}\text { Milch cows } \\
\text { Other cattl } \\
\text { Sheep } \\
\text { Pigs }\end{array}$} & \multirow{4}{*}{$e^{\& \text { heifers }}$} & \multicolumn{2}{|c|}{ Thous'd animals. } & \multirow{2}{*}{ I9.I9 } & \multirow{3}{*}{$\begin{array}{l}24.48 \\
22.73\end{array}$} \\
\hline & & $I, 774$ & 2,264 & & \\
\hline & & $2,73 I$ & 3,453 & 17.84 & \\
\hline & & 20,780 & I7,I30 & 5.94 & I3.I 4 \\
\hline & $\cdots$ & 2,586 & $2, \mathrm{IO} 2$ & I 2.94 & I0.69 \\
\hline & & & & I06.or & 98.08 \\
\hline
\end{tabular}

The table exaggerates the actual output in 1872 as regards quantity, because at that time the yields per acre were somewhat lighter and a given head of stock did not produce so much meat in a year because of their slower maturity, though on the other hand there was less purchase of foreign grain and feeding stuffs in 1872. More correctly the table may be taken to represent what would have been the output in I9I3 had the acreage, etc., remained the same as in 1872 . It will be seen that the value of the output from the increased head of cattle barely balances the loss on the sheep, 


\section{DECLINE OF BRITISH AGRICULTURE}

and if we further take the pigs into account the lessened production of wheat and barley is not compensated for at all by the increase in the produce from the stock. This agrees with the conclusion to be discussed later that a given area of land will produce, when under the plough, in addition to its usual yield of wheat and barley, just as much cattle food as the same area of land under grass.

The number of men employed in agriculture has declined with the plough land; I00 acres of arable land will employ as many as four men, while 200 or 300 acres of grazing can be looked after by a single man. During the forty years under review three and a half million acres have passed from arable to grass, and $26 \mathrm{I}$ thousand men have left agriculture-seven men for each hundred acres that have been laid down. The loss of employment would have been greater but for two causes-the development of certain fruit and market gardening areas which employ a large number of men, and the fact that, as all farmers attest, the average quality of the labourers has deteriorated; the best and most active have been the ones to go into other occupations. On the other hand, farming operations have been improved and call for less manual labour; the introduction of the self-binder alone has enabled the arable farmer to dispense with one of the heaviest of his former calls for labour, and many of the other operations have been cheapened by the use of machines. This is reflected in the fact that the decrease in the number of agricultural horses is proportionally much less than the diminution in the men employed.

The great fall in prices came to an end, however, about I 895 ; since I 900 they have been steadily rising, 


\section{DECLINE OF AGRICULTURAL POPULATION 25}

and with the readjustment of rents arable farming has, during the present century, again become remunerative and attained a measure of prosperity that began to be manifest about I9Io in a widespread demand for farms and in rising rents wherever reletting took place. The conversion of arable to grass did not, however, cease ; the curve shows that it has continued at much the same rate during the present century as in the preceding twenty years; in fact, it has even been accelerated during the years immediately prior to the war, though prices were then still rising. There can be no doubt about the prosperity of the industry from Igro to the outbreak of war. Accounts are available showing that good arable farmers were then making profits of from Io to 20 per cent. on their capital, yet the area under the plough continued to decline. For this fact several explanations may be adduced. In the first place the cost of labour was increasing, and there were difficulties in obtaining and keeping good men. Industrial prosperity and the great agricultural emigration to Canada during the years about Igro drew many of the younger and more energetic men away from the farms. Speaking generally, farmers failed to recognize the changed situation; they only reluctantly and inadequately raised wages to meet the competition for their men; in many cases they preferred to reduce their staff and lay down part of their land to grass. Though they might admit that the higher prices ruling would allow of increased wages, there has always existed a strong personal feeling and even a certain amount of social pressure on the side of the maintenance of the local standard rate of wages, until the farmer felt it almost a duty to his fellows to let a discontented man go rather 


\section{DECLINE OF BRITISH AGRICULTURE}

than meet his demands for higher pay. To a large extent also the farmer felt little confidence in the permanent improvement of the agricultural position; the remembrance of the disasters of the great depression were still strongly with him; he had been bred up to a cautious farming policy, and so preferred to invest his recent profits otherwise than in extending his business. The leaders and advisers of the agricultural community -landlords, agents, solicitors and valuers-continued to take a pessimistic view of the prospects of agriculture long after it has been justified by the actual course of business; with them bad times have grown into a fixed tradition, and, moreover, the whole agricultural community became quite unnecessarily alarmed by the trend of legislation and political dealings with land during the years immediately preceding the war. It should be remembered also that the majority of farmers regard their occupation as providing a living rather than as a means of making money which can be extended and developed. They accept their routine as something inevitable, not susceptible of change-to alter would be "bad farming," whatever the results ; if times are good there is more money to be saved or put aside, but they do not feel called upon to respond to the new opportunities and enlarge their business. They are doing very well as they are, and are not prepared to change from their policy of safety except under pressure. We have in all considerations of agriculture to reckon with the temperament and equipment of the men who are actually holding the bulk of British land at the present moment. Speaking generally, it is not too much to say that they are insufficiently educated and short of capital for the business they have in hand. 
Putting aside a substantial minority and many brilliant exceptions, they have not been touched by the revival of agricultural education that has taken place during the last twenty years and do not take advantage of the technical assistance that is now at their service. Most of all their business training is at fault; they often are capable enough craftsmen, but they are bound within a narrow routine and show no adaptability either in their management or in their buying and selling. On the average farm the expert cannot say " do this " or " use that" and success will ensue; he sees instead a general low level both of knowledge and of management. In every district certain farms stand out; and if the neighbouring holdings, with the same class of land and the same opportunities, were only worked with equal intelligence and energy there would be no agricultural problem to discuss. In many parts of the country it is clear that the farmer is occupying more land than he can properly manage with the capital at his disposal. During the depression, men who could in any way make a living by farming got hold of comparatively large tracts of land, often putting several holdings together; by cutting down expenses they succeeded in obtaining a working profit off these extended areas, and though prices have latterly justified a more intensive policy they still continue to let the land do the work with the minimum of effort on their part. An indictment might be framed against the landlords for not insisting upon higher farming on the part of their tenants, even for not raising rents to the pitch that would force men to a better use of the land they occupy. But landlords were hard hit in the depression, and then learnt to stick to any tenant who could continue to make the land earn 


\section{DECLINE OF BRITISH AGRICULTURE}

something. They had no prospect of getting superior tenants; the industry was not attracting new men with capital and brains; the safe policy for them, as for their tenants, was to rest content with the small returns in sight rather than to adventure on a policy that must increase their risks and trouble. Land-owning in England has ceased to be a business; yet it is only by personal knowledge and hard work that owners can become leaders of their tenants and develop the capacities of their estates. Social tradition on the other hand bade them be content with a low interest on their capital, compensated for by sport and position. Moreover, land always has a monopoly value, and in a prosperous country opportunities come from time to time for profitable sales. 


\section{CHAPTER III}

\section{ARABLE LAND VERSUS GRASS}

ExpLAIN it or excuse it as we will, the fact remains that for the last generation the cultivation of the land in England has been declining: crops have been giving place to grass, and the gross output in quantity, even more than in value, has been diminishing. It is perhaps necessary to elaborate the point that grass land is less productive than arable. Many people have argued that live stock form the mainstay of British agriculture, which remains without rival in the way it has made itself the source and origin of the high-class sires that are needed to improve the ordinary country stock of the whole world. Whether he breeds horses, cattle, sheep or pigs, the progressive farmer in our own Dominions or in foreign countries must come to England for the foundations of his business, and must replenish his herds and flocks from time to time from our pure stocks. Apart from pedigree breeding, it is also argued that the production of milk and meat is both more profitable to the English farmer and more valuable to the nation than the growth of corn. All this may be admitted, and yet the implied corollary is not true-that live stock can only be maintained upon grass land, or that an equal head of stock can be kept upon grass as upon the 
same land under the plough. All land is more productive under the plough, and will maintain more cattle and sheep upon the crops that can be grown than upon the grass which is produced without cultivation. It does not follow that it would be economic or more profitable to plough up the old fatting pastures that are the pride of some parts of England, or again, some of the very heavy clay pastures that are so expensive and uncertain to work, though the limitations as regards the latter are less than is generally supposed. We have as a guide the fact that three and a half million acres have been laid down to grass during the last forty years; all this has once been profitable under the plough, and there can be no doubt that most of it could be brought under cultivation again, for farming operations have now been made cheaper and quicker, more is known as to the amelioration of the texture of heavy land, and drainage is more efficacious. Over very large areas of the country now under grass the pasture is indifferentit will not fatten stock nor produce much milk; when laid up for hay it produces but a poor crop unless the season is favourable; it is only profitable because the rent is low and the expenditure on labour trifling. Much of it ought to be ploughed up from time to time even if it is to carry good grass; when left down for many years the texture of the soil suffers, aeration becomes deficient, and the herbage grows sparse and deteriorates in quality. Without doubt this grass can be enormously improved as pasture by careful management and the application of manures, especially basic slag; but so content is the farmer with the cheapness of the land and of his methods that even this improvement is neglected. The relative production from arable 


\section{LOW RETURNS FOR GRASS LAND 3 I}

and grass land of the same class may be estimated from the following examples:

(a) One acre of wheat will produce 4 qr. grain and $I \frac{1}{2}$ tons straw. This food material fed to cattle will produce $450 \mathrm{lb}$. live weight increase, equivalent to $256 \mathrm{lb}$. of meat, or 360 gals. of milk.

The same acre of land under grass will produce $\mathrm{I} \frac{1}{2}$ tons of hay (including the aftermath), which, when fed, would produce 2 Io lb. live weight increase, or $120 \mathrm{lb}$. of meat, or I68 gals. of milk.

The figures for the conversion of wheat and straw or hay into meat and milk are calculated from the accepted tables for the conversion of food values into meat or milk. In practice it is estimated that when cows are entirely grass fed upon land of this quality, the yield of milk is about I5o gals. per acre per annum. On this estimate the production of meat or milk from arable land is more than double that from the same land under grass.

(b) One acre of grass land supporting breeding stock will produce about I35 $\mathrm{lb}$. increase of weight as calf and $20 \mathrm{lb}$. increase in the weight of the young cow-I55 lb. in all.

The same land when ploughed and farmed under a rotation of wheat (twice), barley, oats, roots, and clover will produce a yearly average of $660 \mathrm{lb}$. of wheat and $330 \mathrm{lb}$. barley, in addition to the same increase in cow and calf, $\mathrm{I} 55 \mathrm{lb}$., from the consumption of the oats, roots and clover hay also grown on the acre of land.

In this second example, if the wheat and barley grain were also fed to stock, the production of meat alone would be more than double that obtained from the grass. 
(c) If we compare the amount of absolute food (lbs. of starch equivalent, see Table VIII, p. 94) grown upon arable land and permanent grass, taking the recorded average yields in Great Britain for the ten years IgOI-I2, we obtain the following figures: Barley, I,7I6 lb.; oats, $I, 576 \mathrm{lb}$.; roots and green crops, 2, 4I $8 \mathrm{lb}$. ; rotation grass, $840 \mathrm{lb}$. ; permanent grass, $645 \mathrm{lb}$. A rotation of three years of grain crops, one of roots and one of seeds, would produce a yearly average of $\mathrm{r}, 653 \mathrm{lb}$. of starch equivalent against $645 \mathrm{lb}$. from the permanent grass; and a Wiltshire rotation of two years of root and green crops followed by two straw crops would produce annually $2,032 \mathrm{lb}$. of starch equivalent. Thus the arable land of the country is at present producing from $2 \frac{1}{2}$ to 3 times as much cattle food per acre as the permanent grass.

Mr. T. H. Middleton (Journal Board Agriculture, XXII, I9I5, p. 520) sets out certain comparisons of the yield from arable and grass land. On grazing land the live weight increase per acre varies from $330 \mathrm{lb}$. on exceptional pasture, to $2 \mathrm{II} \mathrm{lb}$. on medium grass manured and to as little as $50 \mathrm{lb}$. on really poor grass. The milk yields vary from 260 to Igo gallons per acre. Mr. Middleton's estimate of the produce of one acre of arable land is $I 60 \mathrm{lb}$. of live weight increase, together with $315 \mathrm{lb}$. of flour, $448 \mathrm{lb}$. of potatoes, and $494 \mathrm{lb}$. of beer.

From all the evidence we may conclude that the crops from land under the plough, when used for feeding cattle will produce of either meat or milk more than twice as much as the same land will yield when under grass, though as a rule part of these crops are 
more profitably sold. Even in that case the average arable land will produce as much meat per acre as the grass, in addition to the wheat and barley it has to sell. It may be argued that in many districts the prevailing weather is such that the risks attending corn growing make it an unprofitable enterprise ; in that case it has been shown that the cereals can be very largely replaced by rapidly growing green crops-rape, vetches, etc.-by which means the actual production of cattle food is even greater than when corn crops are grown. Despite the doubled production upon arable as compared with the same land in grass, the profit to the farmer may be no greater; it may even be less if the prices of grain are low and those of labour high. Taking the second case outlined above, the wheat and barley produced on the arable land over and above the meat (which is the same on both the grass and arable land) would be worth about 70 s. (wheat at $36 \mathrm{~s}$. per quarter, barley at 32s.). Against this would have to be set about $7 \mathrm{~s}$. for artificial manures, $5 \mathrm{~s}$. for miscellaneous bills, $8 \mathrm{~s}$. for horse hire, and 35s. for labour per acre per annum ; total, 55s. On the other hand, the grazier would have to pay only about 3 s. per acre per annum for labour and horse hire, as he will only employ men at the rate of one man per 300 acres as against three men per roo acres required by the arable farmer. Thus the cash difference in favour of the arable farmer only amounts to I8s. per acre, out of which he has to provide for the interest on capital required (an extra $£ 5$ per acre, equivalent to 5 s. per acre annual charge), the depreciation on his implements, and the much greater risks involved in the business as well as the increased labour of supervision. 
How large the profits may be upon grass land, with its low rate of employment, may be judged from the following abstract from the accounts of a large dairy farm :

Area-about 700 acres, 60 acres arable.

Men employed-five.

Capital per acre- $£ 5$.

Return on capital without charging for management-27.5 per cent.

There is still a very substantial profit on arable land with wheat and barley at the prices assumed above; but the trend of the agricultural returns for the last few years prove the majority of farmers do not consider that this profit makes up for the greater capital required and the constant labour, anxiety and risk attending arable farming. In fact, as long as considerable areas of grazing land are to be hired cheaply the farmer considers that he obtains an easier and safer return on his available capital by grazing than by putting the land under the plough. His personal profit does not coincide with the national interest, either in the direction of the production of food or in the maintenance of men upon the land. The real limitation, however, lies in the lack of skill and enterprise among the farmers of the country taken collectively; in order to obtain a given income a higher measure of these qualities is required by the arable farmer than by the grazier possessed of an equal amount of capital. To the really enterprising arable farmer are open many opportunities for profit that are not available to the grazier: with due skill his farming can be intensified, whereas little speeding up is possible in the output from grass. For example, in many districts we find the arable farmer growing special 
crops from which under good conditions he reaps a considerable return, but which he turns to other uses if the market is unfavourable. He may sow greens, cabbage or broccoli, saleable at good prices on occasion and always utilizable for sheep keep; he may leave some second-cut clover for seed, or make good money out of potato growing. In every part of the country we may see instances of the way a really knowledgeable farmer on the look out for opportunities makes successful departures from the ordinary routine of his business and obtains a general average of profit far higher than set out in the typical case quoted. Success of this kind is dependent upon the farmer himself. We possess farmers full of enterprise, none better; but their example is not generally followed, their methods have not been systematized so as to become the ordinary standard of agriculture. Many farmers are short of capital for the size of their holdings; they cannot, if they would, depart from the routine of the minimum of cultivation; still more are the necessary personal qualities of knowledge, determination and enterprise lacking.

- Under ordinary conditions it would have been wise to trust to the slow but sure spread of education to bring farming up to a higher level. Of late years the necessary fabric of instruction and research has been to some extent provided, its effects were beginning to be felt, and though many people may consider that its action was hampered by our system of land tenure, this, in its turn, would have been reshaped by a more enlightened agricultural community, and the first steps towards enlightenment were being taken. We might have counted on the known profits of agriculture attracting more men and fresh capital into the business, 


\section{ARABLE LAND VERSUS GRASS}

whereupon the increased demand for land would have resulted in the displacement of the farmer who lived by skimming a large area of cheap land; either he would have to give place to a man with more adequate capital, or he would have to yield up part of his land and concentrate his capital on the rest. More intensive methods and a bigger output would have followed; against the increased expenses costs could be reduced by improved organization and the introduction of machinery ; wages would be increased to meet the demand for a more technically skilled labourer. Taken by themselves, improved organization and machinery would tend to reduce the number of men upon the land; but if they are employed to correct the costliness of a more intensive agriculture and an increased productivity, both the requirements of the State for further productivity and more employment, and that of the individual for profit, can be met.

Where the land is in excess, as in the new countries, undoubtedly the maximum production and profit per man is to be obtained by farming wide areas in the cheapest way possible; as soon as the amount of land and not the number of men become the limiting factor intensive agriculture is necessary. Now the paradox that England presents of a limited amount of land in close proximity to the best markets of the world, accompanied by farming that is yearly growing less instead of more intensive, is only susceptible of one explanation - that the amount of land is still in excess of the demand for it on the part of men who are capable of using it to advantage. Owing to the attractions of other industries or to the difficulty of access to the land, the number of really skilful faimers has not 
been recruited rapidly enough to maintain the standard, still less to ensure progress. It was to education that one looked to improve the quality of the men entering upon the business of farming, whereby the competition for and the management of the limited area of land available would be intensified. But the war has cut athwart all such schemes for slow development ; the wholesale disorganization of our social system which must ensue not only provides the excuse and opportunity for, but practically necessitates the adoption of much more rapid and drastic methods of regenerating agriculture in order to meet the double purpose of providing food and employ. ment within these islands.

Assuming, then, that the present position of agriculture is unsatisfactory and is likely to become worse as a consequence of the war, it is necessary to be prepared with an agricultural policy, in which the permanent interest of the State must be held to override the immediate interests of the existing occupiers of land, however content they may be with the profits they derive from the present system. No sudden revolution is possible if only for the reason set out above, that the number of farmers possessed of the desired standard of skill and knowledge falls short of what is required for the proper utilization of our land, and the addition to that number must be a work of time. Much, however, can be done to start better methods and to break down the barriers which confine access to the land to a comparatively limited class; what is needful is that the action of the State, which is necessarily limited, shall be such as will have a continuous and increasing effect upon the industry. We take as starting-point that the State must secure the more 
intensive cultivation of the land of the United Kingdom and an increasing employment of men upon the land, both as an insurance against war and as a means of reducing the national indebtedness. The process of readjustment may involve some cost to the State; but the necessity is as great as that of maintaining an army or a navy, with this difference, that the expenditure is only an investment on which a commercial return will be obtained as soon as the readjustment is complete. 


\section{CHAPTER IV}

\section{POSSIBLE DEVELOPMENTS}

IN order to bring about the intensification of agriculture that is desired, five direct methods of action by the State are available, over and above indirect methods like education or such legislative changes as may remove some of the difficulties attaching to the access to land.

\section{Industrialized Farms}

In the forefront I should place the development in Great Britain of extensive farms worked upon the same principles as large industrial concerns. British agriculture is distinguished from that of other old settled countries by the comparatively large size of its holdings; its typical farm is one of from 200 to 500 acres, and the advanced position that our agriculture obtained during the early years of the nineteenth century - the development of improved methods of cultivation and of our notable strains of pedigree stock and seeds-was due to the enterprise of the larger farmers working with considerable capital. The process has, however, not gone far enough, and the existing tenant farm does not constitute a large enough economic unit to utilize to the full modern developments of organization and scientific knowledge.

This statement does not fail to recognize that actually the holdings in this country are very often too large for the occupier's capital, so that they are worked at a low 
productive level with a comparatively small expenditure on labour per acre. Not only is capital generally deficient, but in many cases where the occupier may be possessed of adequate means his standard of management is so low, his business organization so imperfect, that he relies for his profits upon cheap farming over an extensive area. In most districts one is familiar with the successful farmer, who during the depression learnt how to manage his land cheaply to meet the prevailing prices, and then and since has put farm to farm until he has control of a scattered area of two to five thousand acres. As managers of each of the farms making up his total he employs uneducated bailiffs; the buying and selling is the only part of the business that is unified in his own hands, and even that business is often conducted in the most personal fashion without any system of accounts. There is no organization comparable to that which any other industry of the same magnitude would possess, and the resulting social structure is deplorable. There is one man absorbing the profits of a wide area; below him are only the labourers and the few bailiffs, whose wages are but a little better than those of the labourers; the old farm houses are either let off or are in a dilapidated condition, providing a few rooms for the bailiffs to whom they are turned over.

The suggestion now put forward is that large farms of anything from 2,000 to I0,000 acres of land should be organized and managed as business enterprises, each under the control of a general manager, but with due provision of assistant managers and heads of departments to ensure efficiency in all the stages. There are no special characteristics about farming to 
distinguish it from other business enterprises; its fluctuating returns, its risks, its dependence upon the weather are best met by working on a large scale so as to equalize the chances, and with adequate capital that will obviate the crippling of its methods by one or two bad seasons. Whatever profits are obtainable by the present methods would certainly be increased by working upon a wholesale scale, and the obvious economies that are in sight may be summed up as follows :

(I) Economy in management. Under the present system the land has to support a farmer and his establishment on each 200 acres or thereabouts, whereas a man drawing no higher remuneration from the enterprise ought under proper organization to be able to control four or five times as much land.

(2) Economy in labour. On a small farm machinery cannot be employed to its full advantage; the initial expense and the cost of the special labour required are often so great that they only become profitable when continuously employed or applied over a large acreage, e.g., a motor plough, costing $£ 300$ to $£ 400$, however cheaply it does its work per acre, would be an uneconomic implement on a 200 acre farm. The cost of many farming operations can be reduced by bulking the available labour and directing large numbers to a particular purpose at the proper time.

(3) Economy in buying and selling wholesale, in avoiding waste, in preparing for market by methods that are only remunerative on a large scale. Agriculture supports a disproportionate fringe of dealers and middlemen who live by buying up small lots of mixed quality 
from the producers and then grading and preparing them for the larger market.

(4) Economy in the use of the land itself. Over a great part of the country fields are far too small for cheap working, the hedges and banks occupy a notable percentage of the total area and are in themselves detrimental to the crops. Yet a farmer must have several fields for the convenience of his stock, and when working on a small scale he cannot face the expense of removing hedges, straightening watercourses, and otherwise improving the workability of his farm.

(5) Economies effected by more skilful management. A large enterprise can afford to pay for efficient direction and scientific advice. In particular a proper system of book-keeping can be applied to a large farm, and becomes of the utmost value by the way it enables the direction to review results, detect mismanagement and waste, and drop unprofitable branches of the business. It is impossible to exaggerate the importance of scientific book-keeping on a costs basis; in all modern productive businesses it forms the foundation of the management, yet it has hardly been applied to agriculture in Great Britain. With more efficient management and the criticism provided by exact accounts will come the power of intensifying the production and of testing and developing new lines of business.

Agricultural enterprises of the character suggested are few in the British Islands; they can, however, be paralleled by the estates growing rubber, copra, sugar and other tropical products, but much more closely by the domain farms worked by the great landowners and 
beet sugar corporations in Germany and by certain syndicate farms in the East of France. Figures are difficult to obtain in England, but some idea of the returns that may be expected can be obtained from the following abstracts from the accounts of certain British farms taken for the few years immediately prior to the outbreak of war :

I. About I,000 acres, three-quarters arable.

Capital per acre, $£ 88 \mathrm{~s}$.

Men per 100 acres, $2 \frac{1}{2}$.

Average earnings per man, I5s. 2d. per week.

Profit, after paying 5 per cent. on capital, but including management, I3.I per cent.

2. About 4,000 acres, two-thirds arable.

Capital per acre, about $£$ Io.

Men per roo acres, about 5 .

Average earnings per man, 2Is. 6d. per week.

Management, Ios. per acre per annum.

Profits, after paying 5 per cent. on capital, ro.5

per cent.

3. About 5,000 acres, three-fourths arable.

Capital per acre, about $£ 8$.

Men per 100 acres, 4.

Average earnings per man, 2Is. 6d. per week.

Management, 5s. per acre per annum.

Profit, after paying 5 per cent., I2 $\frac{1}{2}$ per cent.

4. About $\mathrm{I}, 500$ acres, four-fifths arable.

Capital per acre, about fI2.

Men per 100 acres, 7 .

Average earnings per man, 22s. per week.

Management, 5s. per acre per annum.

Profit, after paying 5 per cent. on capital, ro per cent. 


\section{POSSIBLE DEVELOPMENTS}

5. About rooo acres, three-quarters arable.

Capital per acre, £7. Ios.

Men per Ioo acres, $2 \frac{1}{2}$.

Average earnings per man, 2Is. 2d. per week,

Profit, after paying 5 per cent. on capital, but including management, 2 I. 6 per cent.

6. About 550 acres, half arable.

Capital per acre, £Io.

Men per Ioo acres, 3 .

Average wages per man, I6s. per week.

Profit, after paying 5 per cent. on capital, but including management; I6.I per cent.

It may be explained that the gross production per acre is not given, because this figure must vary with the style of farming adopted-for example, a business which buys store stock heavily and fattens them to a large extent on purchased feeding stuffs will show a far larger gross output than an equally profitable business. which purchases little and depends entirely upon the sale of crops. The profits shown represent the net proceeds after rent, manures, labour and all outgoings have been paid, and after 5 per cent. has been set aside as interest on the capital employed in the undertaking. In the cases of 2 and 3 the management charges are set down too low; they represent what had been actually paid, but they take no account of the considerable supervision exercised by the proprietors of the respective businesses. It should also be pointed out that the six enterprises in question, though differing widely in character, are normal agricultural businèsses, deriving their returns from farm crops, stock and milk, and not from fruit, market garden produce, pedigree stock or other special developments. Theaccounts are abstracted 
for a period in which the farms were in full working order; in some of the earlier years when the land was being got into shape the profits were much less than are here set out. Different as are the conditions prevailing and the intensity of farming in the several enterprises, they do provide one common basis from which the results of industrial farming on a large scale may be estimated. The figures given may be recalculated as under, to show the total earnings per annum for each man employed, using total earnings in the sense of the net proceeds per man, out of which his wages, management expenses, interest on capital and profits have to be paid:

Farm I.-Per Ioo acres. $£$ s. d.

Wages : $2 \frac{1}{2}$ men $\times 52$ weeks $\times$ I5s. 2 d. $=98$ II 8 Gross profit, I8.I per cent. on $£ 8.8$ per acre $=I 52$ o Io

$$
£ 250126
$$$$
\div 2 \frac{1}{2}=£ \text { roo.6 per man per annum. }
$$

Calculating by the same method we obtain for Farm 2, £97 per man per annum ; for Farm 3, $£ 97$; for Farm 4, £9I ; for Farm 5, £I20; for Farm 6, £99 per man per annum.

It will be seen that the figure for total earnings per man per annum comes out to a sum which is about the same in each of the six businesses: approximately $£$ Ioo, and is independent of the style of farming followed or the number of men employed upon a given area. This provides a means of estimating the probable earnings of a large industrialized farm. Assuming that an area of 5,000 acres can be obtained 
of land that is ordinarily rented at 20 s. an acre or a little less, we may expect that at the outset about onehalf can be worked as arable land, and that three men can be employed per 100 acres or I50 in all, exclusive of the staff required for management. The actual number that can be profitably occupied will depend upon the quality of the land; but it would be wise to begin quietly, without any large departure from the system of farming previously followed, and to intensify the agriculture by degrees. A living wage must be paid; this may be taken at an average of 20s. per week with a free cottage and garden, equivalent to $25 \mathrm{~s}$. a week in cash. Allowing for boys and old men among the employees, this average rate of 20s. would permit of a higher wage for a certain proportion of foremen; the total annual labour bill for I50 men would come to $£ 7,800$. It may be expected that the estate will be insufficiently provided with cottages; if fifty additional cottages have to be erected at an average cost of $£ 200$ each, the business will have to bear an annual charge of $£ 600$, allowing 6 per cent. for interest and repairs. The expenses of management may be estimated at about $£ 3,000$, made up as follows:

One general manager charged with the direction and the buying and selling .. Four assistant managers, each overseeing

a section of the estate..

One machinery manager and two skilled

\section{mechanics}

Book-keeper and two clerks Travelling, stationery, etc.
$£ 800-£ 1,000$

$£ 800-£ 1,000$ $£ 400-£ 450$ $£ 300-£ 350$ $£ 350$

$$
£ 2,650-£ 3,150
$$


Such a staff would be ample for an estate of 5,000 to 8,000 acres. Assuming, then, that the gross earnings per man amounted to $£$ Ioo per annum, as in the examples quoted, and that interest on the price of the land is treated as rent and included in the outgoings before the gross earnings are calculated, the divisible receipts will amount to $£ I 5,000$, out of which interest has to be provided on a floating capital of $£ 40,000$ at $f^{8}$ per acre. The profit and loss account therefore becomes :

Earnings of 150 men at $£$ I00 per annum $£ 15,000$

$£ 15,000$
Interest on capital at 5 per cent. $\quad \ldots £ 2,000$ Interest on cottages at 6 per cent. $\quad . \quad £ 600$ Wages $\quad . \quad \ldots £ 7,800$ Management $\quad \ldots £ 3,000$ Balance $\quad \ldots \quad \ldots £$. $£ 15,000$

The balance plus the interest makes up a total return of 9 per cent. on the floating capital invested in the business, which may be considered as a satisfactory return considering that the labourers are being paid not on the basis of existing rates of wage but what a reasonably prosperous and permanent industry ought to pay. Were the enterprise treated as a profit-sharing scheme the balance would be sufficient to pay a dividend of I2 per cent. on salaries, wages, and interest, making the labourers' cash wages average 22s. $6 \mathrm{~d}$. per week and the interest on the floating capital over $5 \frac{1}{2}$ per cent. On the other hand, as the farm gets under way, it must be 
expected that the farming will be intensified and a larger number of men employed upon the same area. This will add to the total earnings without increasing the capital, management, rent and other of the outgoings in the same proportion, thus raising the divisible profits of the enterprise.

The advantages of such a scheme of industrialized farming, other than the possible profits to the capitalist, are twofold. In the first place it is necessary to raise the wages of the agricultural labourer. Except in certain districts he is the worst paid workman in the country. His numbers and quality have been steadily declining through emigration and the competition of better paid industries, until in many districts only a residuum of partially capable or inefficient men are being left upon the land. This transference to other occupations is likely to be accelerated by the war ; men who have enlisted and have thus experienced higher rates of pay, who have also once been uprooted and violently disturbed in their routine of life, will at least make an effort not to go back to the old conditions. Higher wages means that the labourer must receive a greater share of the returns derived from farming, and this becomes possible upon the industrialized farm by the fact that a given area of land has not to carry so many masters and admits of other economies in working. Whether the agricultural labourer can ever be paid wages equivalent to those prevailing in other industries for men of no greater skill must depend on the extent to which the labourer can be rendered more efficient and capable of a larger output. This is most likely to occur on a large farm where organization, contract work, and the use of machinery can be given full play. 
Ultimately the wages that can be paid must be limited by the prices of agricultural produce; but whatever these conditions may be in the future, it is on the large farm that production will be cheapest. The agricultural industry cannot continue to depend upon the existence of a wage standard much below that attainable elsewhere. It is not to the national interest that it should do so ; the present ignorance and lack of independence of the rural labourer arise ultimately from his poverty and weaken the fibre of our population.

On the other hand, the existence of a graded system of managers and under-managers upon large farms would provide openings for young men of trained intelligence but without capital. Ourgreat industries and commercial enterprises are staffed by such men, who have come in at the bottom and proved their value. One reason for the decline of agriculture in Great Britain has been that it has been deprived of men of this type. Few men without capital of their own can make a start in farming, and a large number of the young men trained in our agricultural colleges, many of them possessed of capacity out of the common but who have no family farm to go back to, must obtain administrative or teaching posts or go abroad in order to find adequate employment. The agricultural colleges are often reproached because of the small proportion of their students who are to be found afterwards engaged in farming; but this simply arises from the fact that the majority of their students are not sons of farmers nor do they possess any capital beyond their education, and the conditions of agriculture prevailing in England afford them no opportunity of entering upon a business career. No industry can continue to prosper unless it is 
continually recruited by intelligence, and farming has suffered doubly in that the more enterprising sons of farmers have been tempted away by the greater possibilities of commerce and manufactures, while at the same time the business has been closed to the great bulk of the community, who cannot be given a substantial sum of money for their start in life. In France or Germany it is always easy to find for the management of an estate or agricultural enterprise, young men who have added to a scientific training an apprenticeship in a similar business ; such men are rare in Great Britain because of the lack of opportunity of obtaining practical training in a subordinate capacity.

It will be argued that agricultural enterprises of the type suggested are unlikely to be successful, because farming is a business that cannot be reduced to a system, as is demonstrated by the almost universal failure of rich men and corporations who take it up under the management of paid servants. Farming, it is argued, is a personal business, dependent primarily on the acumen and determination of the farmer in his buying or selling-qualities that are only developed by men working for their own pockets. So much is the business affected by these personal factors, so little is it determined by mere knowledge or organizing ability, that it is useless to attempt to treat it industrially; better leave it to the enterprise of a number of individuals working independently, some at least of whom will manage to make a living. Such a view, which is only another manifestation of that disbelief in the value of intelligence to which Englishmen are prone, is no more true of farming than of any other business. The alleged failures have been conspicuous enough 
and might have been predicted beforehand. How often has one seen men, otherwise possessed of sound commercial instincts, put a farming business in which they have invested $£ 5,000$ or so under the control of a bailiff at $£ 2$ a week. Or, if a gentleman has been selected for the management, his qualifications have generally been negative rather than positive, an incapacity to make a start in other walks of life instead of a thorough apprenticeship to the knowledge and business of agriculture. It is true that managers of the right type are rare here, for reasons set out above; but some can be found and others can be trained, for the material exists. Farming is not a mystery open only to those born within the craft ; it is just as susceptible of exact knowledge and hard business treatment as any other industry. If we are to believe that agriculture is outside the scope of British intelligence and organization, the sooner we put up the national shutters the better, for that kind of mental dry rot will not be confined to agriculture. Now is the time for experiment, when the close of the war provides the opportunity for the regeneration of all our industries on a basis of brains.

It is not suggested that the industrialized large farm outlined above can become, either by natural growth or by legislative action, the normal type of British farming within the near future. It does, however, so manifestly represent the direction the development of the land of the country should take, both in the interests of agriculture and of the nation as a whole, that the State ought to institute one or two examples in order to demonstrate the possibilities attached to farming on this scale. If these experiments proved as 
successful as may be anticipated, further developments along the same lines would rapidly follow. The State itself in the widest sense, including the Crown, the Ecclesiastical Commissioners, the Universities and the Colleges, is already by far the largest landowner in the country and should set the example of the most economic utilization of the land. The great landowners, a class that has always recognized their duty of leadership and their obligations to the community, would not be backward once it was proved that both the interests of the nation and their own profit were assured by a new method of dealing with their land. Even if they were unable to provide the capital necessary for the enterprise, the demonstration of the profits attainable would be sufficient to attract the joint stock company to undertake farming as it does any other business that has been systematized. The British capital that has gone in the past to finance gold mines, railways, even land companies in other countries, could find just as profitable an outlet in the development of British land if once the tradition of the insecurity and the personal character of the business can be broken down. Meantime the demonstration farms proposed for establishment by the State would provide a training-ground for the skilled managers who would be wanted.

\section{Small-holding Colonies}

A second method of securing a larger population resident upon the land and more intensive cultivation consists in the establishment of small holdings held under the State or County Councils on a perpetual leasehold or such terms of amortization as will eventu- 
ally render the occupier the owner of his holding. Certain progress has already been made in this direction under the Small Holdings Acts ; in many parts of the country there was, prior to the war, a considerable demand for land, and it is generally held that this demand will be increased when the troops are demobilized, and that the extension of the process of setting up such small holdings will go far to bring about an intensification of British agriculture. The question of leasehold or ultimate ownership does not appear to weigh much with the actual small holder, provided he is assured of security of tenure. He is mainly concerned with getting as low a rent as possible and wants to have the whole of his available capital free for his business. Various arguments of a political nature may be urged for and against ownership. Experience would seem to show that the small owner is always tempted to mortgage his land, and that when a cycle of bad times occurs the small holdings get sold and thrown together.

The advantages of a small-holding system are perhaps more social than agricultural :

(I) They meet the requirements of men of a certain type with a considerable strain of independence and self-reliance in their temperament, who perhaps work badly or irregularly under orders.

(2) They provide a starting point for agricultural workers who begin at the bottom, but have the capacity for rising.

(3) They call out great reserves of hard work and ingenuity in their occupiers, and so give rise to a class of men of value to the State because of their capacity for continuous labour and their independence. Their 
children, too, are early broken to hard work and are bred up without the temptations to the dissipation of energy which beset a town dweller.

(4) The setting up of small holdings generally brings about an intensification of the farming of the land on which they are situated. In order to live at all the occupier of Io or 20 acres cannot be content with the return per acre satisfactory to the large farmer; the small holder must, therefore, break up grass land and cultivate it as a market garden; if he is producing milk he must stock his land heavily and buy food from outside.

On the other hand, the disadvantages of small holdings may be summed up as follows:

(I) The independence of the small holder is often purchased dearly at the cost of the excessive labour of the occupier and the "sweating " of his family.

(2) There are many losses and failures, both at starting and when a series of bad years occur.

(3) In themselves, small holdings are necessarily uneconomical units for dealing with land. Most farming operations become much cheaper when carried out on a wide scale ; the use of machinery is only profitable on large fields and when the machine can be given a full measure of work in proportion to its cost. The large farmer is more likely to apply science and bring knowledge to his business; the small holder must be conservative in his methods, and generally becomes very unprogressive. Though the personal attention that the small holder can give to details may be supposed to be of special value in the handling of milch cows, the management of fruit, 
etc., in practice the organization at the command of the farmer on a large scale secures an equal or a better result. It is true to say that in districts where intensive cultivation is practised by both small and large occupiers, the actual cultivation is better, the gross production and the net profits are larger upon the holdings of 50 to Ioo acres than upon those of from 5 to 20 acres. In fact, the really good small holder soon gets possession of a larger acreage, and ceases to be a small holder.

(4) It follows that small holdings are only likely to answer for such forms of agriculture as produce a large gross return per acre, and when the proportion that manual labour bears to the other costs of production is high. This almost confines successful small holding to the production of vegetables, fruit, and flowers; as regards the production of meat and corn, and to some extent of milk, the small holder cannot compete with the large. It is doubtful whether the market for fruit and vegetables is capable of considerable expansion; it is indeed probable that after the war it will shrink with the general poverty of the nation and only extend again slowly. Akin to this restriction is the fact that small holdings only answer on good land, or at any rate on light land that is responsive to fertilizers and easily worked. They must also have good access to markets. Many large areas in the kingdom - the chalk uplands, the clays of the Midland counties, can be profitably farmed on a large scale but cannot produce rapidly enough to satisfy a small holder.

(5) The small holder, with his limited capital, is at 
a disadvantage both in buying and selling. When buying he only requires small quantities of materials like fertilizers and feeding stuffs; he is confined to the local market, freight charges are increased, and he finds it more difficult to insure himself against inferior quality or fraud. His difficulties are increased in selling; as he cannot grade his produce or turn out a large bulk of uniform quality he falls into the hands of dealers and middlemen; he has to pay excessive freight charges on small lots; he finds particular difficulties in disposing of the inevitable surplus of inferior quality. The small holder is most successful when he can work up a private connection and use his own labour to deliver, as, for example, when he establishes a milk round in some neighbouring town; but obviously this method of disposal of produce is only open to the minority.

It is, however, very generally maintained that these disadvantages of the small holding system can be largely if not entirely removed by the adoption of co-operative principles both for cultivation and trade, so that the whole area of a small-holding colony would become a single economic unit, combining the advantages of wholesale management with the individualism and hard work fostered by separate ownership. In practice we do not find that the principle of co-operation has obtained any firm grip in smallholding districts, particularly in those of any standing. Nevertheless, a small-holding colony should be provided with the framework of a co-operative organization at the time of its settlement, so that from the outset the occupiers may be led to work as units of a 
collective enterprise under the guidance of an expert adviser who would instruct the occupiers as to the crops they could grow most advantageously and the methods of cultivation to adopt. The society would own the necessary machinery and horse labour, and the adviser would organize the rota on which it circulated ; ploughing, cultivating, and all operations involving power or machinery would thus be carried out by the society at cost, leaving to the occupier the processes involving manual labour only. The occupier would purchase all his necessaries-manures, seeds, tools, etc., through the central depot at wholesale rates plus the expenses of management ; he would bring his produce to the depot, where it would be graded, properly packed, and sold in bulk. The depot for a fruit and vegetable producing colony would thus involve a packing and grading station and an installation for pulping, canning, drying, and other processes for dealing with gluts and utilizing inferior produce. For a colony of stock farmers the depot might take the form of a cheese factory or creamery, an egg-collecting station, etc. ; it would also own and control the necessary sires of high quality. On a larger scale the slaughter of cattle and the sale of meat, the manufacture of bacon, etc., might be undertaken cooperatively; but in the early stages at any rate it would seem desirable not to undertake these very special commercial enterprises, which are not in essence the business of the producer. Until the co-operative society is very strong both in its organization and its finance it should confine its operations to securing a standardized production and sale on wholesale terms. The business of co-operation is not to get rid of the distributors, dependent manufacturers or middlemen, 
but to ensure that they are only remunerated for the services they render and do not also capture the profits of production, as they do when the producers are unorganized and can be induced to compete with their fellows to bring down prices. At present the producer is often allowed only a bare living wage; the middleman engrosses all the margin of profit. By co-operation the situation can be equalized, if not reversed.

The conception of a co-operative colony of small farmers is certainly attractive, and in its elements is to be found at work in numerous agricultural co-operative enterprises in Great Britain and Ireland. But no complete colony, organized for cultivation, buying and selling, has yet been realized; there is this great inherent difficulty in its foundation, that the temperament of the men who make the best small holders-one of independence and self-reliance-is averse to the discipline and subordination involved in co-operative working. It must be remembered also that the cooperative society is itself a middleman like any other, and that the organization for advice and management is a charge upon the enterprise as costly if not more so than the parallel organization upon a large farm. Compared with the industrialized farm the small-holding colony will be a less efficient and more expensive producer; it is also indifferently adapted to farming for wheat and the other staple crops, and to the breeding and fattening of cattle and sheep. The establishment of a colony of small holders would also require more capital than would be wanted for an industrialized farm of the same area and giving employment to the same number of men, because of the extra cost of 
buildings, fencing, roads, etc., necessitated by the multiplicity of holdings.

Nevertheless, as small holdings are justified by their social advantages, as they respond to certain real if not universal factors in human nature, the State may be expected after the war to continue and extend its former policy of promoting their creation and financing their establishment out of public funds. Having gone so far and because the security for its loans depends upon the prosperity of the holders, the State should even in its own interest go a stage further and divide up no estate into small holdings without at the same time setting up an organization for co-operative working, which alone can enable the small farmer to compete with the large producer.

The setting up of the machinery for sale and purchase and for technical guidance should precede or at least be contemporaneous with the settlement of the small holdings, so that the occupier finds it in being when he takes up his land. Otherwise he is liable to waste much of his small capital by injudicious purchases before he has acquired experience, and again he forms trading connections which he finds difficult to break when at some later period the organization of a co-operative society is attempted in his district. The grip of the trader who has given credit to the small holder or farmer paralyses his already limited powers of buying and selling to advantage; one of the functions of the cooperative societies will be to give their members the legitimate credits they may require in a form less perilous to their independence.

If, however, the co-operative society is to come into existence at the same time as the small holdings, it will 
have to be organized and in its early stages financed by some outside agency, like the Agricultural Organization Society, to whom the State has delegated the development of co-operation, the cost of the initial stages being treated as a necessary preliminary expenditure in the establishment of the colony, like road-making or fencing, This procedure may involve some departure from the strict principles of co-operation, some paternalism ; but the start is all-important and new tenants are rarely in a position to take the initiative. After all the State has become the landlord, and the landlord has duties towards his tenants beyond the mere receiving of rents.

Organized into a co-operative framework, smallholding colonies can become important agencies in carrying out the object of the State-the better utilization of the resources of the land, both in the way of the increased production of food and the support of a larger rural population. It may be doubted whether they will ever be as efficient as large industrialized farms; but they are correlative and not antagonistic to such large farms. They have certain social virtues of their own and respond to deep-seated instincts and aspirations in human nature. Above all they provide openings, and by their help new men get a footing in the ranks of the farmers.

\section{The Intensification of Agriculture under the Current System}

It has already been shown that the productivity of the land of Great Britain as a whole has declined during the last forty years, as a result of the great depression consequent on the fall in prices towards the close of the nineteenth century. From this depression the industry 
had only very partially begun to recover as prices improved in the period immediately prior to the war, though in many parts of the country, as, for example, among the Lincolnshire potato growers and the market gardeners, men of enterprise are to be found who are utilizing the advantages derived from better fertilizers, better varieties, and improved machinery that have accrued during the last generation, men who have increased the capital employed in their businesses and are making highly efficient use of their land. Nevertheless, in many districts, especially on the poorer soils, the majority of the holdings are under-farmed and undercapitalized, and the farmers are making their profits out of the natural capacity of the soil to yield some return on a very small expenditure of labour. Some very bad cases of what we may term the exploitation of the soil, as distinct from farming, can be found. In one case one man obtained, in the 'eighties, partly by purchase and partly by hiring, the control of some 8,600 acres, which has ever since been worked as a vast sheep farm. On the portion owned the whole of the land has been laid down to grass; the cottages, and in many cases the farmhouses and buildings, have been allowed to fall into ruin, and two hamlets have been completely depopulated. Just prior to the war, on one property consisting formerly of five farms and totalling I,360 acres, two men only were regularly employed, three of the farm houses were let to private residents, two were left empty. On another group of $I, 500$ acres four men were regularly employed where about seventy once found work. On the rented farms, where a certain proportion of arable has to be maintained, it was estimated that about seventy men and boys remained 
instead of the I6o or so who were once employed. The land, though much of it is high and poor, lies on the chalk, and is all susceptible of arable cultivation. It would be difficult to exaggerate the wholesale loss to the community that has been brought about by this deliberate conversion of what was once a productive and fairly populated area into a sheep ranch. The occupier, however, has found his profit in dispensing with labour, and, as things are, no one can interfere with his methods. Under normal conditions it might have been hoped that with the returning prosperity of farming the various educational agencies that have been set up during the last twenty or thirty years-agricultural colleges, farm institutes, institutes for research, etc.-would slowly, but in the most enduring fashion, effect a reform in the conduct of the industry and bring up its general level more nearly to that of the practice of the best men. Withou i doubt the attitude of the leaders of agricultural opinion towards knowledge and investigation have been changing very greatly. The best men expect assistance from science, and keep their minds open to apply its teachings and to reduce to practice the openings it indicates. Education in the business as well as in the science of farming was going forward, co-operative methods were making headway among large farmers as well as small, and co-operation in itself has an educational value. Example, education, the trend of prices were alike making for progress, until the war introduced a fresh feeling of insecurity. Now, even the stimulus of high prices is more than set off by the difficulties arising out of the lack of labour, the scarcity of manures, feeding stuffs, and machinery, the congestion of traffic, etc. ; cultivation is declining, good 
men are leaving their farms, and the question remains of what steps can be taken to ensure that after the war the existing occupiers of land shall set about better methods and face the risks involved in a more intensive use of the land.

Should the schemes that have already been outlined for the creation of large industrialized farms and smallholding colonies develop to such an extent that they take up any considerable proportion of the cultivable land of Great Britain, there would be a sensible reaction upon the rest of the land in the direction of improved farming. For example, if one-half of a large estate were to be withdrawn in order to establish a single large farm, either room for the displaced tenants must be obtained by dividing the holdings upon the rest of the land, or in the alternative such a competition would be set up for the untouched holdings that a selection could be made of none but the best of the old tenants, and a higher standard of farming could be ensured. Thus over the country as a whole the influx of new tenants and new capital that is postulated by either the large industrial farms or the small-holding colonies, must promote the better utilization of the remaining land, both by bringing about division of the existing undercapitalized farms and the concentration of more capital and effort on a given area, and by the more stringent competition that would be set up for the remaining farms. As has been said before, landowners have often to rest content with indifferent farming on the part of their tenants, because they cannot be sure of finding any better ones; the greater the competition for farms, and the higher the rents the owner can hold out for, the more intensive must be the farming in order to earn the rent 
out of the land. Of course the statement that higher rents make for better farming is not true as a general proposition ; but it is sound to say that a condition of no competition for farms, so that the owner has to take any rentals he can be reasonably sure of, is generally accompanied by low farming and restricted enterprise on the part of the tenants. It is for this reason that the mere granting of security of tenure to the sitting tenant, taken by itself, is not likely to further the improvement of agriculture. The freedom it would give the farmer to develop his holding and embark capital on new ventures without the risk of having his rent raised or his improvements confiscated, would be valuable to men of enterprise, especially to those who wish to take up fruit growing and market gardening; but these men are in a minority, and the majority, who are making what they regard as a sufficient income out of their cheap methods, will be confirmed in their restricted policies. In practice only a few farmers, anxious to develop, find themselves restricted by the present conditions of tenure; the real problem, inherent in the renting system, would still remain of how a farmer or his representatives are to realize the value of either a special business that he has built up or the general improvement on a holding that he has brought up to a high pitch of cultivation. The burden of obtaining a purchaser of the improvements would have to be left to the tenant, for the owner can hardly be called upon to take over a speculation in which he has not participated from the outset. Security of tenure and free sale of improvements are without doubt necessary to encourage farmers of enterprise, but they must be accompanied by certain safeguards to ensure that the land is made full use of. One very real 
objection to granting security of tenure now without qualification is that rents are, speaking generally, below their true economic level in England. Why should the tenant be presented with that excess of the real over the rental value of the land which is not being realized, just because of his own indifferent farming or because the owner for social reasons and the lack of competition is not in a position to enforce a more adequate development of the capabilities of the land? Apart from temporary fluctuations, such as that induced by the fall in prices towards the end of last century or the changes the war may bring, land in Great Britain must be expected to rise in value as time goes on, for reasons beyond the control of either owner or tenant. Little is to be gained by handing over this unearned increment from the present owner to the sitting tenant; indeed, such a creation of a dual ownership would only put new obstacles in the way of the resumption of this interest by the State, which has the only real title to it.

The most effective lever to secure the better farming that is now needed in the national interest would be to give the State powers to take over any land that is being inadequately used; the State could then develop this land either on the large farm system or by settling it with small-holding colonies. In this way pressure would be put on the owners of land to make the most of it, pressure arising on the one hand from increased competition owing to displacement and on the other from the implied threat of dispossession if the occupier is allowed to farm badly. But if the State is to be given power to take over land that is not being fully utilized, it must also be prepared to farm the land itself on one or other of the methods indicated. The 
justification for such drastic measures is the critical situation into which the nation has drifted and the imperative necessity of developing the production of food on our own soil, but these measures cannot be adopted until the State is ready to manage the land itself.

In this connection there is an urgent call for the special education of our rising generation of landowners. If we consider the land-owning class in this country from any broad general standpoint we must recognize that they have accepted certain public obligations as attached to their receipt of rents. They have endeavoured to be just and liberal to their tenants; they have not pressed for the full measure of the value of their land; they have given freely both of their time and their resources to the community. The one thing they have lacked has been technical knowledge; only in the direction of pedigree stock-raising have they advanced the national agriculture ; they have not treated landowning as a career nor qualified themselves to give a lead to their tenants. Nor have their agents brought a more enlightened outlook to their profession; the best of them have managed the business of rent receiving, the letting of farms, the carrying out of the owner's obligations in the way of buildings and repairs, carefully and soundly. They have acted as considerate and wellinformed intermediaries between the owner and his tenants, but with a few exceptions they have not attempted the development of the industry upon the land under their charge. They have taken the system as they found it, and have thought, perhaps, more of the ease of the tenants than of the pockets of the owners. But this, I submit, is not enough. The 
landowner, if he is to retain his position, must become the leader of his tenants and the entrepreneur of his property. His very kindness, his acceptance of noneconomic rents, his easiness towards unprogressive tenants in difficulties, has injured rather than helped the industry as a whole. The root of the evil lies in the owner's want of technical knowledge of the land; he leaves school and university without any education directed towards his future position, with a certain inherited sense of public duty but with no means of applying it to his immediate powers and obligations. It is true that there are now Schools of Agriculture both at Oxford and Cambridge, but as yet they have been but little utilized by the land-owning class. At both Universities the curriculum is primarily based upon science; the schools aim mainly at training agricultural experts and officials, to a less extent practical farmers. The schools enjoy no social consideration in the Universities; the course of instruction, which at the outset involves a considerable measure of work in the laboratory, is somewhat repellent and abstract to the student whose previous upbringing has been literary and classical, and whose sole agricultural asset is some personal acquaintance and sympathy with the life of the country-side. If he came up from school with a reasonable knowledge of the elements of chemistry and botany his entry into the subject would be facilitated; he would, as it were, know the language in which his technical instruction has to be given. But the real objection to the current types of education lies in the fact that the working landowner need neither be a man of science nor a practical farmer, valuable as the knowledge of either might be to him; he has to become 
the administrator of a specialized business, and should be taught how such a business is susceptible of study and exact management. His education should, therefore, be based upon economics, upon law and social history; he should be shown the way into the consideration of markets and co-operation. If there is one technical subject he should be made familiar with it is that of book-keeping, because of the power it gives a director to review the progress of a business and to obtain exact data as the basis for action. It is easy to sneer at book-keeping as a pettifogging matter of shillings and pence unworthy of a University, but it is the intellectual basis of affairs, as fundamental as the principle of conservation of energy in science, and no sound judgment in business can be formed without it. "Things are what they are, and consequences will be what they will be ; why, then, should we deceive ourselves?" It is not pretended that the young landowner can be turned out of the University equipped for the business of controlling or developing a great estate ; real education begins after the University; but he can be given the broad principles of action; he can be made acquainted with the sources of information and awakened to the possibility of applying exact methods to practical life. Let no one pretend that it would be a derogation on the part of a University to concern itself with education of this type. Those who are acquainted with the travesty of intellectual effort that is represented by the pass schools of either University, or even by the lower classes of the Honour schools, can but view with equanimity their replacement by any form of instruction that will, on the one hand, be likely to kindle some mental response on the part of the 


\section{AGRICULTURAL EDUCATION}

recipient, and on the other begin to qualify him for his position in the State. In the critical years of the next generation the landowners of this country and the system they represent must expect a searching and even a hostile trial ; it is for the Universities to enlighten them on the opportunities and the obligations that are bound up with the possession of land.

It has already been stated that the country, prior to the war, was being provided with a fairly complete organization of agricultural research and education. The skeleton of the system existed, though in many cases, especially in the purely rural counties where the education is most needed, the local authorities were slow to take advantage of the opportunities provided for them. What is needed is that the Board of Agriculture should be given power to insist that a backward authority shall bring its educational work up to a certain standard. The Board of Education possesses this power with regard to the provision of primary and other forms of technical education; the Board of Agriculture can only advise and assist. Grants-in-aid alone are not sufficient to convince the farmer who sits on County Councils of the value of education, the county rate is a more substantial argument. There would seem to be room for the introduction of a new type of instruction in business methods by the setting up of demonstration farms run solely for profit, but which keep a strict set of accounts and make public the costs and results of every part of their work. Such farms are particularly needed in districts where it is desirable to bring about a change in the current routine of farming, for example where men are dairying upon grass land, but where better results can be obtained by 
the introduction of a certain amount of arable cultivation for cattle food. In such circumstances example will have more effect than any amount of lecturing.

The question of internal transport, again, requires careful examination in the interests of better farming. Though preferential rates to the foreign producer are not allowed, without doubt they do exist in the form of combined rail and steamship rates at a level designed to meet the competition of a possible purely water-borne traffic. Apart from these actual cases of preferential treatment the British farmer compared with similar producers in other countries is heavily handicapped by high internal freights. It is not only in marketing his produce that he suffers, but the cost of carriage is a serious item in the price of materials like lime and fertilizers; his production would be improved if he could make more use of seed corn, seed potatoes, etc., from a distance ; in many directions the high railway charges oppose an obstacle to the introduction of improved methods.

\section{The Reclamation of Land}

The area of land under cultivation in England rose year by year from the date at which exact records begin up to 1892 ; since then it has declined similarly year by year, about 800,000 acres in all having been lost. In the main this loss represents urban encroachments which have no longer been balanced by the bringing into cultivation of portions of the margin of waste still existing in the country. The work of reclaiming, which had been most active towards the middle of the last century, proceeded in two ways: occasionally, on a large scale, as a landlord's enterprise ; more 
generally by the enterprise of the tenant farmers, who, with or without improving leases, gradually drained and cleaned up the rough land adjacent to their holdings. The process stopped with the great fall in agricultural prices; the cost of the labour to clear the land ceased to be repaid by the value of its produce, for at that time labour was the main, almost the only item in the cost of reclamation. In Great Britain no new factor has arisen to alter the situation. In Germany, however, the march of events has been very different; the cultivation of the waste lands-moor and heath-has been taken in hand in increasing areas year by year. For example, in the small province of Oldenburg, about an average of sixty settlers per annum were placed on reclaimed land between Igor and I9Io; but the numbers rose to I30 in I9Io and I66 in I9II, each colonist possessing some 20 to 25 acres of land that had been added to the cultivated area. So convinced of the economic soundness of the process had the State become that in I9I3 the Prussian Diet sanctioned a loan of $I \frac{1}{4}$ millions sterling, half of which was to be devoted to State schemes of reclamation, $£$ r50,000 to drainage, and $£ 500,000$ was to be used in subventions to provincial schemes of reclamation. This contrast between the action of the two countries is not to be accounted for simply by the difference in fiscal policies and the higher prices for agricultural produce ruling in Germany; it is, in the main, due to the fact that the Germans had studied the problem and were employing modern resources, both in the way of knowledge and materials, to the treatment of the land. The same process has been going on in the free trade countries of Holland and Belgium. In Great Britain no advance 
had been made upon the methods in vogue at the beginning of the nineteenth century; when a piece of the waste was to be taken in the land was drained where necessary, the rough vegetation was burnt off, the soil broken up, the only treatment other than mechanical being a dressing of lime. Once cleaned, the land was put under the ordinary crops, with, as a rule, extremely poor results for many years, though eventually, by dint of perseverance and an annual expenditure that was in the aggregate considerable, though perhaps not large in any one year, the land accumulated fertility and became a paying proposition, like the little farms one sees everywhere bitten out of the waste on the flanks of the New Forest, on the Bagshot Heath and the Surrey wastes. The German land reclaimers, on the other hand, have recognized that the natural infertility of the heaths and moors is in the main due to their deficiency in mineral salts-lime, phosphoric acid and potash-and after the mechanical operations of drainage and clearing had been effected they set themselves to remedy this deficiency by an initial expenditure on fertilizers that would appear to a farmer enormous for such land, but without which even a moderate crop cannot be grown. In this way the land at once becomes capable of yielding a living return for the labour of cultivation; the initial outlay on basic slag and kainit proves to be much less costly than the recurring losses involved in growing crops with no special manuring until some sort of fertility is built up. Indeed, in many cases one sees that the existing farms reclaimed from the heaths in Great Britain are still suffering greatly from their original deficiencies; their productivity is at a low level because, even after 
half a century or more of cultivation, the soil is still short of lime, phosphoric acid, potash-sometimes of one constituent, sometimes of all three.

It is necessary to emphasize this general statement : that land reclamation as practised in Great Britain has never taken into account the chemical constitution of the soil and its possible rectification by cheap mineral fertilizers, largely because the process was already falling into disuse by the time these fertilizers became available, and because few landowners have had sufficient confidence in the situation or faith in science to embark capital on agricultural enterprises during the last thirty years. It is for this reason that such accounts as are available of the costs of land reclamation in England afford no guidance to the possibilities that are open. They sometimes show good results where the land was initially healthy as on Lincoln Heath, or where plentiful supplies of town refuse were available as in Cheshire, Bedford, or parts of Surrey ; elsewhere they have been unremunerative, and have led to the widespread tradition that the most ruinous of all proceedings is to try to turn bad land into good.

Before discussing the different types of waste land. that are capable of reclamation in Great Britain, it is, perhaps, advisable to render the term more precise by excluding those forms of improvement that may be regarded as within the scope of a tenant holding a lease of reasonable duration. Many examples of rough waste land occur that can be profitably brought into cultivation by ordinary means-e.g., fields of clay land overgrown with briers and brambles, which only require clearing and draining, with a dressing of basic slag, to convert them into decent grass land. The term F 
"reclamation" is better reserved for such cases as involve a preliminary expenditure of capital on a scale comparable with or greater than the initial value of the land, beginning with certain defined operations which are apart from the ordinary routine of cultivation. Reclamation deals with land, the initial value of which lies between $£ I$ and perhaps $£ 7$ per acre as an upper limit, and the outlay before the land can be let for ordinary farming may be as high as $£ 7$ an acre, irrespective of buildings and roads.

In Great Britain opportunities for reclamation on a reasonably large scale are to be found as follows :

(I) Salt marsh and slob lands under water at high tide. While no great area of this debatable ground exists, payable areas ripe for reclamation are to be found in many of the estuaries of our rivers, particularly on the East Coast. Round the Wash the process has always been going on, and could now be resumed with advantage; other areas have been examined in the Dee Estuary, the Firth of Forth, Cromarty, etc. The process is well understood; it consists in throwing up a wall round the area, embanking any streams and providing them with outlets, cutting drainage channels and providing them with sluices to discharge at low water or by means of a pumping station. In the Eastern Counties experience has shown that it is rarely wise to embank land that has not already been so far built up by natural actions as to have acquired a green covering of vegetation. The embankment is comparatively costly in labour and varies with the size and shape of the area; but the land gained is nearly always of high quality, worth from $£ 30$ to $£ 50$ an acre. Perhaps the chief obstacle to the prosecution of such work is the 
uncertain nature of the title to areas of this kind. In the main the property resides in the frontager. The Crown possesses certain ill-defined rights, but rarely can make use of them except to deal with the frontager, the more so as the strip to be reclaimed is often only accessible by leave of the frontager.

(2) Areas of blown sand adjoining the sea. On the coast of North Wales several large areas of this kind are to be found; next the sea comes a line of dunes, behind which is a comparatively level stretch covered with rough grass and rushes, the soil being almost pure sand. To reclaim these areas the dunes have to be fixed by planting with Austrian and maritime pine, gorse, elder, marram grass, etc. ; a few drainage cuts are often necessary, then the light soil is readily brought under cultivation. This type of land is well suited for market garden cultivation, both by its ease of working and proximity to the sea, provided that it is liberally supplied with phosphatic and potash manures at the outset. Some of these areas contain a certain proportion of strong alluvial soil adapted to corn growing and akin to the valuable land adjoining the Wash and the Humber. The cost of the preparation of the land for cultivation is low, but the charge to be met depends in each case upon the proportion the cultivable area bears to that of the dunes requiring fixing. In some cases too high a price is demanded for areas of this kind that are capable of profitable reclamation, because of their possible value for development as seaside estates.

In character intermediate between this type and that previously described are certain areas that are neither links nor slob land. In one case there exists a block of about six square miles of land only commanding a 
few pence per acre for rough grazing, that is in part strong alluvial soil, in part peaty and elsewhere sandy, a large proportion being subject to flooding at high spring tides. The work required is embankment, drainage, possibly a pumping station, and special manuring on the peaty and sandy portions of the area; but the cost would be small in proportion to the ultimate value of the land to be gained for cultivation.

(3) Heath. In England there exist comparatively large expanses of uncultivated sandy heath, now covered with a valueless vegetation of heather or bracken and worthless grass. Such is the "brek" land of Norfolk and Suffolk, other heaths further south in Suffolk, land upon the Bagshot Sand formation and Lower Greensand in Surrey; Sussex and Hampshire. the Dorset heaths, etc. The reclamation of this type of land has been reduced to a system in Germany. After drainage where necessary, the clearing of shrubs and bushes and levelling of any mounds or banks, the surface is pared and allowed to rot for a winter, or if a meadow is to be formed, a tilth is obtained by continued cultivation with implements of the disc type. At the same time about 2 tons per acre of chalk or its equivalent, $8 \mathrm{cwt}$. per acre of kainit, and $5 \mathrm{cwt}$. of basic slag, are worked in as the fundamental preliminary dressing, these quantities being increased if a meadow is in preparation. For a meadow a special mixture of grass and clover seeds are sown directly on to the shallow-worked surface with surprisingly good results. For the arable land the best preparation is to grow a crop of lupins the first year and turn that in, thus increasing the stock both of nitrogen and humus, and binding and adding to the water-holding capacity of the soil. Afterwards the land will grow all 
the cereals, especially rye and oats; potatoes, carrots and peas give good crops, and lucerne also answers well on such land. Liberal manuring with artificials is required in the early years ; the cost is made up by the cheapness of cultivation. In Germany as much as $£ 7$ an acre has been paid for such heath land; the reclaiming, including the ploughing in of the lupin crop, costs $£ 5$ to $£ 6$ per acre. After two or three years' cultivation the land sells at $£ 20$ to $£ 30$ an acre. A small experiment is in progress by the Development Commission on 200 acres of land of this class in Norfolk, formerly let as a rabbit warren ; in the second year 136 acres were under crop, and though the season (I9I5) was unfavourable, they yielded per acre $27 \frac{1}{2}$ bushels of wheat, 28 bushels of oats, I 7 bushels of peas, and $65 \mathrm{cwt}$. of potatoes (crop badly hit by disease). The cropping of I36 acres that had been reclaimed in the previous year cost in I9I4-I5, $£ I, 05 I$ - the receipts are estimated at $£ I, 330$. Despite difficulties with regard to labour and the dearness of the indispensable potash manures, the reclamation of the 160 acres, which are now clear and ready for ordinary cropping, has not cost more than $£ 5$ per acre, exclusive of management and administration, charges for which have been heavy on so small an experimental area. It may be estimated that land of this class, having initially a letting value of $2 \mathrm{~s}$. to $3 \mathrm{~s}$. an acre (exclusive of sporting rights), may be given a letting value of $I_{5}$ s. per acre by an expenditure on reclaiming proper of about $£ 5$ an acre. Buildings have also to be provided, but the cost is low, because no horned stock has to be provided for, and may be set at about $£ 5$ per acre (reckoning half the cost of cottages to be covered by their rent). The reclamation of this type of land 
would, therefore, just pay its way; but the land improves with cultivation, so that in twenty years' time it would be worth a further $5 \mathrm{~s}$. or so per acre. In many cases there are obstacles to the acquisition of land of this type in the existence of common rights, often of the smallest value to the commoners, and in the Eastern Counties in the high value attached to the land for sporting purposes.

(4) Low-lying moor and bog. A few areas exist in this country where the land is water-logged and is covered by a thick accumulation of peat. Such are the carrs and moors near the mouth of the Trent, and a few inland areas. The reclamation of land of this type has been very thoroughly studied in Holland and Germany, and in Friesland and North Germany flourishing colonies of small arable farmers may be seen on such moors that formerly carried only a crop of rough grass. As the reclamation depends upon thorough drainage the scheme has to be a comparatively large one in order to deal with all the sources of incoming water or to straighten and deepen the river channel so as to lower the water level on the drowned land. When the surface is dry the deficiencies in phosphoric acid and potash, and often in lime, have to be repaired as on the heath land; but the accumulated vegetation provides a great asset in the shape of nitrogen, which becomes available when the mineral salts are supplied, so that the reclaimed lands carry good crops. Sometimes it is remunerative to remove the lower layers of peat for fuel, and it is often desirable to bring a layer of earth or sand to the surface. The cost varies with each scheme, according to the extent of drainage required, the value of the peat, the proximity of mineral soil, etc.; but areas of 
this type are regarded in Germany as the most profitable of all.

To what extent similar processes can be extended to the higher-lying peat and bog areas in places like Dartmoor, parts of Wales, the North of England and the Highlands is doubtful, because the climatic conditions are often too severe to permit of profitable crops to be grown. For the present, at any rate until more experience has accumulated, it would not be wise to touch land of this kind except by way of experiment on selected favourable areas, as, for example, on some of the cut-over bogs in Ireland.

(5) Upland sheep walk. In many parts of the country, notably in Mid Wales and the Lowlands of Scotland, lie extensive tracts of grassy uplands which have never been improved in any way, and are held as farms of I,000 acres and upwards for breeding sheep which are sold away and fattened on the lowlands. In Mid Wales many thousands of acres of land of this type are let at rentals of about Is. per acre. They possess a fair mineral soil, though, as a rule, deficient in lime; the herbage is rough and poor, but consists in the main of grass; boggy patches occur in which peat has accumulated. Being purely grass land, game are scanty, and the sporting rights of little value; on the other hand certain commoners' rights often exist, though there are few commoners to exercise them. From the evidence afforded by neighbouring farms it is certain that this land is capable of profitable development, and that much of it is cultivable when the situation is not too exposed nor the slopes too steep. The difficulty of communication has been the main reason why the land has not been divided into smaller farms 
and improved. The work of reclamation would begin with the construction of roads. The better land by the stream courses would be prepared for arable cultivation by drainage and the use of basic slag and lime; the steep slopes would be best utilized for forestry; while the higher land would be still left as sheep walks, to be improved by the occupier as time went on. After the preliminary operations, what would be aimed at would be the creation of small farms of 150 acres or so of the better land, 20 to 30 acres of which would be under the plough and the rest improved grass, while to each farm would be attached a stretch of sheep walk above the forest. The forestry and the farming would react favourably on one another, as the forest would provide for the occupiers of the farms winter occupation in planting and maintenance, the labour for which would - be otherwise unobtainable in those districts. The relative proportion the forests would bear to the farms would depend upon the configuration and elevation of each district. It is not possible to frame any general estimate of the expenditure and returns for reclamation of this kind, but as the rentals run as high as I2s. an acre for farms in Wales on precisely the same class of land, and at similar elevations as that which, in its unimproved state, only commands Is. to Is. $6 \mathrm{~d}$. per acre, and the buildings and fences cannot be set at more than $£ 4$ an acre on the existing farms, there is a considerable margin for expenditure. The cost of the roads should not be wholly debited to the reclamation, as they will to a large extent be paid for in the increasing rating of the area. None but schemes on a large scale, however, offer prospects of ultimate success, and some time would elapse before they became paying propositions. 
It may be estimated that the gross expenditure on the reclaimed land (regarding the afforested portions as a separate enterprise) would be $t^{8}$ to $€$ Io an acre before the farms could be let, and for the first year or two the rents would have to be kept low, not rising to the normal for at least five years. But supposing that half the land has to be put in forest, it would ultimately carry a family per 300 acres, where it now only carries a family per $\mathrm{I}, 500$ acres.

One aspect of reclamation work that has not hitherto been considered is that it would afford a considerable volume of employment for large gangs of unskilled labour during the preliminary period of actual reclamation. Most of the work that requires to be doneembankment, drainage, levelling, clearing, etc., roadmaking and even building - could be done under direction by able-bodied men with no previous experience of the land. For example, regiments awaiting discharge could well undertake such work on a prepared scheme with a small amount of technical direction, the huts that have been erected in so many camps about the country being moved to supply the necessary housing. As the work progressed and became more definitely agricultural, the men with a desire to remain in the country and some aptitude for farming, could be selected to become the occupiers of the holdings that had been prepared for farming, and since the occupiers would form definite colonies it would be easy to provide some technical guidance in the earlier years.

In conclusion, it should be said that the full value of reclamation schemes is only apparent after the lapse of time, for the true capacity of the land is only attained after years of cultivation, and the best uses to which it 
can be put in any district are only learnt by experience. Many of the advantages also are indirect; the land won is sheer gain to the cultivated area, no previously existing labour is displaced, and the increased population provided for, as well as the absolute addition to the production of food, enhance the wealth of the nation both by the commercial exchanges promoted and the new contribution of rates and taxes.

\section{Subsidiary Agricultural Industries}

One of the evils from the social point of view that has overtaken the country-side during the last sixty years has been the gradual decay of the minor industries depending upon agriculture. The corn mills and the tanneries have largely been concentrated in the ports and the towns; the wheelwrights and the harnessmakers have become more shopkeepers than manufacturers; the farriers often buy their shoes ready made; the country towns and villages have lost their old craftsmen. To some extent the process is inevitable, and has been due to the normal centralization of industries and the comparative efficiency of large businesses as compared with small. There are, however, sundry definitely agricultural industries which can most properly be conducted in close proximity to the land from which the raw material is derived, but which have suffered from the neglect and lack of enterprise that have overtaken all matters agricultural during the last half century. One example is the manufacture of beet sugar. It has been fully demonstrated that sugar beet of quality equal to the best continental produce can be grown in England, and that the beet sugar crop would find a place profitable to the farmer in the systems of 
farming in vogue in several parts of the country. It has not been demonstrated-indeed, it cannot be demonstrated by figures which do not represent resultsthat the beet sugar industry will be an economic success in this country; nothing but an actual full scale trial can settle this question, yea or nay. The one factory that has been established has laboured under considerable difficulties, some due to the pioneer character of the work, others to the foreign direction and the resulting unfamiliarity with English farming conditions. The factory is still at work, but for these and other reasons the men who are best qualified to judge do not consider that even a failure of this enterprise could be taken as finally demonstrating that the manufacture of beet sugar must be unprofitable in England. Losses must be expected in the early stages of a specialized new industry of this kind; if for no other reason, because of the time and cost required to educate the farmers on whom the supply of raw material is dependent. But having regard to the importance of producing a part of our imports of sugar and the valuable element that the beet crop has proved to be in the agriculture of other countries, there is every justification for an experiment on such a scale and with such a reserve of capital as will give the industry a thorough working trial after the initial difficulties have been overcome. There are other possible rural industries with regard to which a prima facie case can be made out for a trial on a commercial scale, a trial that will be experimental on both the agricultural and the manufacturing side. Such are the preparation of flax and hemp fibre, the canning of fruit, the drying of vegetables, basketmaking, the utilization of timber waste, the growth 
and extraction of drugs, the conversion of certain crops into industrial alcohol, the preparation of starch.

In several of these directions the Development Commissioners have already instituted experiments upon a small commercial scale, but neither that body nor the Board of Agriculture possess sufficient powers to go to work with the directness and on the scale that is required for the inauguration of a new industry. Neither body can participate in or initiate industrial ventures in the way that is possible to the Agricultural Departments of our Dominions and other countries. There are many minor rural industries which are entirely neglected in the United Kingdom, small perhaps in themselves, but which if successful would go far towards increasing the prosperity of the rural population and at the same time add to the stability of our agriculture by extending the variety of its output. 


\section{CHAPTER V}

\section{THE CAPACITY OF THE LAND FOR FOOD PRODUCTION}

IT now remains to consider what can be effected in the way of increasing the national food production, for any radical disturbance of existing conditions of farming can only be justified if it accomplishes something substantial towards making the nation self-supporting in time of war. We take as our initial criterion of what is possible the extent of the arable land in 1872 , the year in which it reached its highest point.

The following table, No. VI, summarizes the position in 1872 and I9I3:

TABLE VI.-AREA OF CULTIVATED LAND, ARABLE LAND AND WHEAT IN I872 AND I9I3

\begin{tabular}{|c|c|c|c|c|c|}
\hline & $\begin{array}{c}\text { Total } \\
\text { cultiva- } \\
\text { ted area. }\end{array}$ & $\begin{array}{l}\text { Arable } \\
\text { land. }\end{array}$ & $\begin{array}{l}\text { Arable } \\
\text { land. }\end{array}$ & Wheat. & $\begin{array}{l}\text { Wheat } \\
\text { per cent. } \\
\text { of arable } \\
\text { land. }\end{array}$ \\
\hline England I 872 & $\begin{array}{l}I, 000 \\
\text { acres. } \\
23,830\end{array}$ & $\begin{array}{l}\text { I,000 } \\
\text { acres. } \\
\text { I3,839 }\end{array}$ & $\begin{array}{c}\text { Per } \\
\text { cent. } \\
58.0\end{array}$ & $\begin{array}{l}\text { I,000 } \\
\text { acres. } \\
3,337\end{array}$ & $\begin{array}{l}\text { Per } \\
\text { cent. }\end{array}$ \\
\hline ," I9I3 & 24,375 & 10,362 & 40.8 & $\begin{array}{l}3,657 \\
x, 663\end{array}$ & I6.I \\
\hline Wales, I872 & 2,636 & I,I04 & 42.5 & I 26 & II. 4 \\
\hline ," IgI3 & 2,755 & 696 & 25.3 & 38 & 5.5 \\
\hline Scotland I 872 & 4,538 & 3,485 & 76.8 & I36 & 3.9 \\
\hline I9I3 & 4,798 & 3,302 & 68.8 & 55 & I.7 \\
\hline Ireland, I872 & $\mathbf{5} 5,747$ & 5,505 & 34.9 & 228 & 4.2 \\
\hline I9I3 & $\mathrm{I} 4,69 \mathrm{I}$ & 4,979 & 33.9 & 34 & 0.7 \\
\hline U.K., & 46,869 & $24,03 I$ & 51.3 & 3,840 & I6.0 \\
\hline I9I3 & $46,74 \mathrm{I}$ & I9,432 & $4 \mathrm{I} .6$ & $\mathrm{I}, 792$ & 9.2 \\
\hline
\end{tabular}


The most striking feature of the change is that in England alone more than three and a half million acres of arable land have been laid down to grass since 1872 . That acreage ought certainly to be recovered for the plough, not necessarily the same fields, but an equivalent elsewhere, for even in 1872 there was a disproportionate amount of grass in Great Britain. But any land which paid then for cultivation can be worked nowadays more cheaply in proportion to the output, if for no other reason because of the introduction of the self-binder and the motor plough and cultivator since I872. The actual cost of cultivation may not have been greatly reduced because of the rise in wages, but the value of machinery lies in the power it gives of speedy working so that the farmer can utilize better the opportunities afforded by the weather. Hence labour has become more effective, and from that and other causes the output has been increased.

It has been objected that much of the land thus laid down in the last forty years has now become so improved as grass land that it ought not to be ploughed up; but if it is good grass land it will make the better arable land. If its capacity for responding to cultivation, and not the profit it will earn without any labuur, is to be the criterion of whether land should be left in grass or not, then the factor deciding on the side of grass will be the degree of heaviness and wetness rather than of richness. Even a fatting pasture will produce much more cattle food under the plough, though as pasture its productivity may be high enough to justify its retention in grass. But we are not concerned with the fatting pastures; the bulk of the grass land in the country could, at best, only be described as useful, and with skilled 


\section{OBJECTIONS TO PLOUGHING UP GRASS 87}

management and a due expenditure upon labour would pay the farmer just as well under the plough, while it would yield for the nation more than twice as much food in the shape of meat or milk, or ten times as much in the form of grain. Again, it is often urged that to plough up much of the poor grass land would be to unlock a ruinous heritage of weeds which are best left undisturbed now that they are safely covered. This is in essence a plea that bad farming must continue because the ordinary tenant with limited capital will not face the risk of bringing the land back into good condition. It is, of course, true that the rehabilitation of neglected land is always an unremunerative proceeding for the first year or two; but the cost of cleaning, like that of setting the drainage in order or reforming the fences, is to be regarded as part of the necessary capital outlay that must precede the attainment of a higher level of cultivation. While the occupier tries to make out that ploughing up old grass is costly, on the other hand the owner maintains that established grass land represents a certain amount of capital in the shape of accumulated fertility, of which he will be deprived for the benefit of the tenant if the land is put under the plough. As the old adage runs: "To make a pasture breaks a man; to break a pasture makes a man." This proposition is perhaps more generally true than the preceding one. In most cases the man who ploughs up old grass brings into use plant food that has been slowly accreting year by year while the land was in pasture and can convert it into saleable crops; he can take his profit therefrom and leave the land foul and robbed of this fertility. This assumes, however, a temporary tenant who has no intention of continuing to farm the land in question ; 
he is to be guarded against in the same way as any other exploiting tenant who goes about looking for a good arable farm, only that he may run it out. The relation of owner and tenant is one of partnership, and the onus is always on the owner to see that his working partner does not dilapidate his property. Though the latent value is there in the grass land it is not productive, and does not in the majority of cases cause the land to bring in more rent; as long as there is reasonable security that the land will remain under arable cultivation and will continue to earn the same rent, the owner is not put in a worse position by the conversion of grass into arable. He may have paid something for the laying down of grass as a permanent improvement, but his loss is only realized if it becomes impossible to continue the arable farming and he is called upon to restore the grass. But under our cardinal assumption the extension and continuance of the arable farming are necessary to the welfare of the State, so that the loss should never accrue, and in any case a mode of insurance or guarantee can be devised against the possible replacement of the grass. The landowner has doubtless a just claim that he and not the tenant only ought to have the benefit of the latent fertility in old grass land. A tribunal would therefore appear to be necessary to assess this value in cases of dispute, and also to decide to what extent the owner's restrictive covenants against the ploughing up of grass land should be allowed to stand.

Let us now consider the method in which the land now under cultivation is distributed among the various crops, and the cropping that might be obtained if we could bring about a return to the same acreage of arable 
land as prevailed in 1872 . It would be our aim, however, to increase the wheat as much as was consistent with good farming, because from the point of view of national safety wheat is the absolutely necessary food of which a large stock must be maintained in the country. If a real crisis came and the country were threatened with starvation, not only can the ration of meat be materially reduced without danger, but there would always be a large reserve of meat in the country in the shape of the breeding flocks and herds. It must also be remembered that the production from a given area of land in the form of corn and other vegetable materials will in time of real need support about eight times as many men as will the meat obtainable from the same land. From eight to ten pounds of absolute food of vegetable origin are consumed in making one pound of absolute food in the shape of meat; in other words, a vegetarian population can exist on the produce of oneeighth as much land as would be required by purely meat-eaters. Without anticipating that it would ever be necessary to resort to vegetarianism, an economy can be effected during a time of scarcity by altering the general diet in that direction and consuming vegetable produce instead of first converting it into meat. But this economy is only possible if the land is under arable cultivation and can be cropped with wheat, oats, potatoes, beans, etc., which can be used either as human or cattle food, whereas grass land produces meat only. We shall not, however, have gained, in times of peace, if the increase in bread corn is purchased at the cost of the existing supply of meat and milk; from the financial point of view we want to increase both, but in a crisis the first necessity is to have wheat. 
In order to obtain a more precise idea of what may be obtained in the way of food production both for men and cattle by an extension of the arable area, the following table has been drawn up on the supposition that the acreage under the plough can be restored to the position it occupied in I872, and that a maximum area of wheat is grown. It is not suggested that the cropping indicated is the best possible or that which would probably be adopted if farmers increased their arable land to such an extent; the table is merely an illustration which reduces the results of the change to figures. Taking the distribution of crops in Great Britain in I9I4 as a starting-point for comparison, and increasing the arable to its area in 1872 , Table VII shows the proposed distribution of crops and Table VIII the amount of cattle food produced on both plans. Ireland has been left out of the account because the manner in which the land is mainly held in Ireland renders any rapid extension of tillage difficult of attainment. On the large grazing holdings there are neither men, implements, nor knowledge of arable cultivation. On the other hand, the small proprietors who have just enough land to earn some sort of a living by grazing, with two or three acres under little better than spade cultivation, will always be slow to move in the direction of arable farming and can hardly be subjected to legislative pressure to ensure a more intensive utilization of the land.

In the example given, the area under wheat is increased by $3,340,000$ acres, which, on an average yield of $4 \mathrm{qr}$. per acre, would raise the home production of wheat from about 20 to about 57 per cent. of our requirements, or rather to 59 per cent. of our requirements if the average production of the five years 


\section{PROPOSED DISTRIBUTION OF CROPS $9 \mathrm{I}$}

\begin{tabular}{|c|c|c|c|c|}
\hline 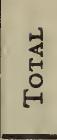 & 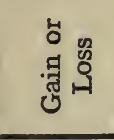 & 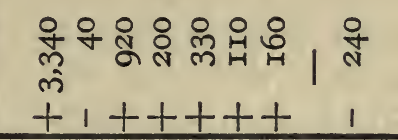 & 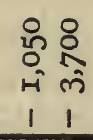 & \\
\hline \multirow{3}{*}{ 是 } & \multirow{3}{*}{ 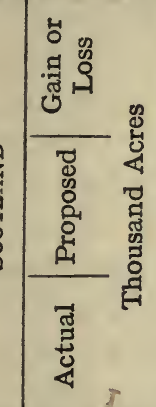 } & $\begin{array}{l}\text { 암유ํ } 11 \text { 워 }|1| \\
+++\quad+\end{array}$ & \multicolumn{2}{|l|}{$\frac{8}{\sqrt{7}} 1$} \\
\hline & & 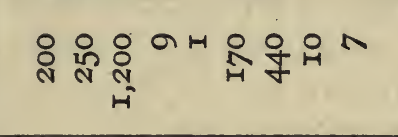 & 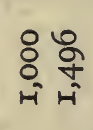 & 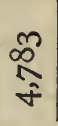 \\
\hline & & 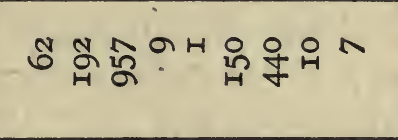 & 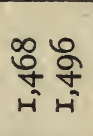 & $\begin{array}{l}\text { \&ू } \\
\text { f }\end{array}$ \\
\hline \multirow{3}{*}{ 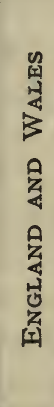 } & \multirow{3}{*}{ - } & 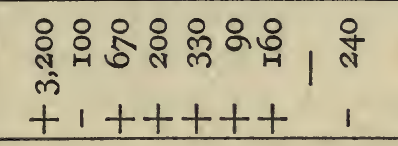 & \multicolumn{2}{|c|}{$\begin{array}{l}\text { 용 } \\
\text { ณn } \\
\text { लิ } \\
1 \\
1\end{array}$} \\
\hline & & 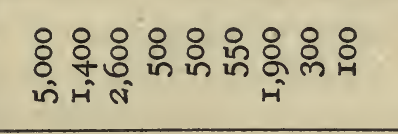 & 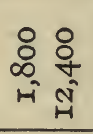 & $\begin{array}{l}\text { in } \\
\text { ลे } \\
\text { ลे }\end{array}$ \\
\hline & & 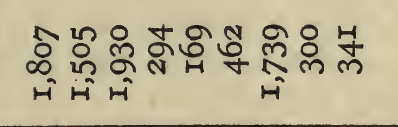 & 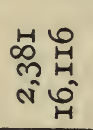 & $\begin{array}{l}\text { J } \\
\text { ลิ }\end{array}$ \\
\hline & & 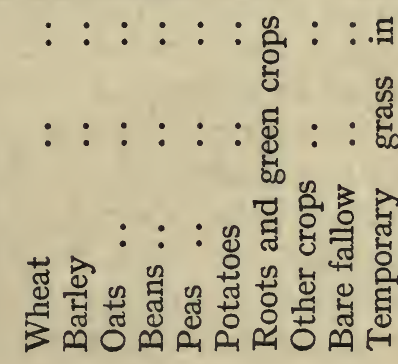 & 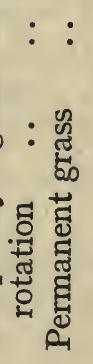 & \\
\hline
\end{tabular}




\section{2 \\ LAND FOR FOOD PRODUCTION}

I908-I3 is taken as the starting-point instead of the actual production in I9I4.

It may be argued that if $4 \mathrm{qr}$. per acre is the present average yield, the land to be broken up would not yield so much, because it is just the land best suited to the crop that has been kept for wheat growing. This is in part true; on the other hand, the factor determining the laying down to grass was cost of cultivation not yield; in the main it was the "wheat and bean "land that went to grass.

The barley acreage is to be decreased by 40,000 acres in view of the steady fall in the demand for and the price of barley; the better qualities of home-grown barley are sold for beer, the consumption of which is likely to feel the effects of the poverty of the country after the war. For feeding purposes, barley is better replaced by oats, of which an increase of 880,000 acres is set down. Peas and beans are to be increased considerably; they find a place in the rotation, enrich the land, provide valuable cattle food and human food in an emergency. An extension of potatoes by II0,000 acres is suggested; this increase would be more than sufficient to replace the main-crop potatoes that are now imported from foreign countries. The total value of potatoes imported amounts to $£ 2,000,000$ per annum; but much of this is for specially early potatoes, which may be regarded as articles of luxury that are not necessary. Root crops are to be increased by 160,000 acres, and without doubt the amount of cattle food grown on the given acreage can be still further added to by replacing the swedes to some extent by vetches, rape, cabbage and other quick-growing green crops. The extra acreage required for these extensions is to be 


\section{GAIN OF CATTLE FOOD WITH ARABLE 93}

obtained by borrowing from the grass both temporary and permanent, though in Scotland the permanent grass is not to be touched, because in that country the additions to the grass land have in the main been obtained by leaving down the temporary pastures for a longer period. If we assume that all the crops except the wheat and potatoes are used in the main for cattle food, the net result of these changes would be to produce at home, instead of importing, wheat to the value of $£ 24$ millions per annum (wheat at $35 \mathrm{~s}$. per qr.) and potatoes to the value of two million pounds per annum. The effect upon the production of cattle food is calculated out in the following table, which is based upon the average production for the ten years I903-I2 and upon the accepted ratios for the conversion of the crops grown into food units for the production of meat and milk on the one hand or work on the other.

Instead of a loss the replacement of three and a half million acres of grass land by arable crops would result in a gain in the total number of units of cattle food produced, over and above the wheat and potatoes added to the supply of human food. The gain is even greater than the figures indicate, because much of the food grown on the arable can be used for fattening and rapid increase, whereas the grass and hay replaced are only available for the maintenance and slow growth of the animal. The only change required in the feeding would be the greater utilization of the straw in many parts of England; in Scotland it is already for the main part consumed as food. Could the straw be subjected to some partly mechanical and partly chemical process of predigestion, its feeding value would be greatly increased. Short of this 


\section{LAND FOR FOOD PRODUCTION}

\begin{tabular}{|c|c|c|c|}
\hline \multirow{3}{*}{ 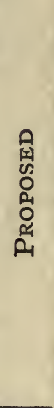 } & 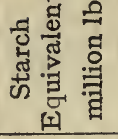 & 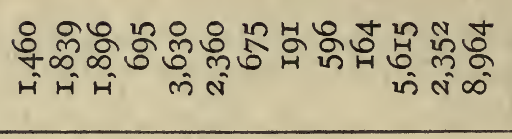 & $\begin{array}{l}\hat{m} \\
\text { o } \\
\text { m }\end{array}$ \\
\hline & 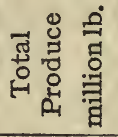 & 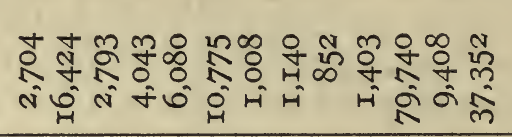 & \\
\hline & 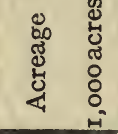 & 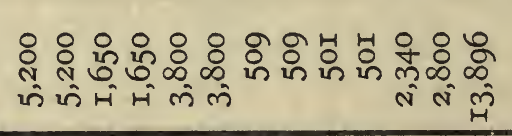 & \\
\hline \multirow{4}{*}{ 展 } & 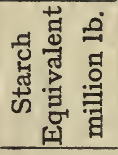 & 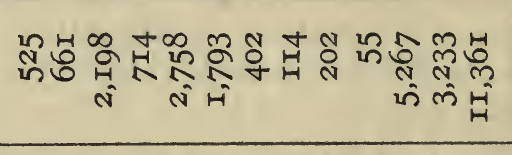 & 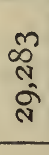 \\
\hline & 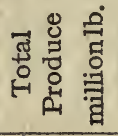 & 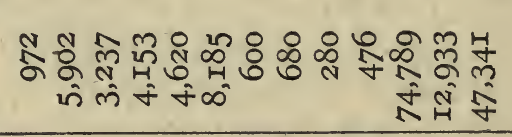 & \\
\hline & 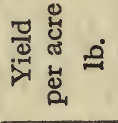 & 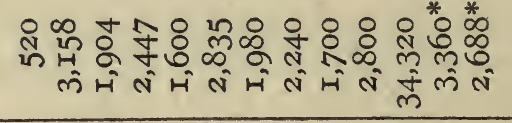 & \\
\hline & 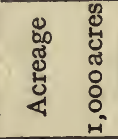 & 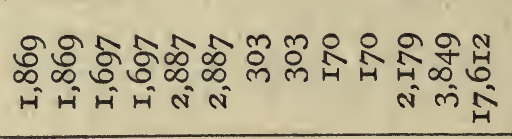 & \\
\hline & & 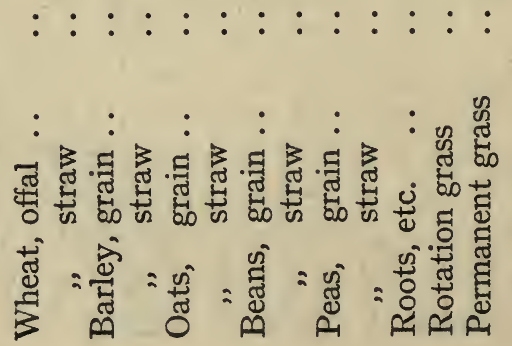 & \\
\hline
\end{tabular}




\section{GAIN OF CATTLE FOOD WITH ARABLE 95}

process it is probable that better use can be made of straw in feeding by chaffing it, mixing it with some succulent green crop and converting the mixture into silage.

The barley imports would not be affected, and though the additional oats grown very nearly equal the amount imported from foreign sources, we are assuming that they are not to be regarded as replacing these imports, but as part of the cattle food required to make up for the grazing and hay that has been lost by the extension of the arable land.

It may be argued that the redistribution suggested would upset the proper rotation of crops and therefore could not be realized in practice; but taking round numbers it only represents Io acres of corn crops to I of beans or peas, 3 of roots and potatoes, and 3 of clover and rotation grasses. There is plenty of experience to show that under modern conditions as to the supply of fertilizers and machinery for cultivation, corn crops can be grown continuously on land of average quality with perhaps a break of one year in six for some cleaning crop. The proportion of corn actually suggested, ten years out of seventeen, is exceeded in many existing rotations ; in Norfolk, for example, it is customary to grow three corn crops in a five-year rotation, and four in a six years' shift is not uncommon in some districts. The programme suggested involves the breaking up of about 4 million acres of grass land; assuming that every advantage was taken of labour-saving machinery, we can expect that at least two additional labourers will be required per Ioo acres of new arable land. There would thus be an addition to the population now supported upon the land of from 80 to Ioo thousand men, 


\section{LAND FOR FOOD PRODUCTION}

even if the general character of the farming was not intensified.

This extra acreage of arable land cropped as indicated would raise the proportion of wheat grown in the country from 20 per cent. to 59 per cent. of our requirements. Now we should not wish to displace the importations of wheat from India, Canada, Australia and other British Dominions, which amount to about 30 per cent. of our requirements. We can assume that imports to that extent would always reach the country, however stringent the blockade, and as they are paid for within the Empire the bill does not depreciate the national credit. There would, therefore, remain a further Io per cent. of our consumption still to be derived from foreign sources, to replace which would require another 880,000 acres under wheat.

As the situation with regard to wheat is the crux of the question from the point of view of national security in time of war, the following table sets out the facts, taking averages for the five years I909-I3 :

\section{TABLE IX}

Total imports of wheat, grain and equivalent of flour in grain ... ..=Ir8.I million cwts. Inports of wheat and flour as above :

From British Possessions.. $\quad .=55.0$

From foreign countries .. ..=63.I ", ", Production of wheat in the United

Kingdom $=59.64$ million bushels $=31.9$ Average consumption of wheat in

United Kingdom $=$ II $8 . \mathrm{I}+3 \mathrm{I} .9=\mathrm{I} 50$ Arable land required to grow the foreign imports at 32 bushels or I7 cwt. per acre $=3.7 \mathrm{I}$, acres. 


\section{ARABLE REQUIRED TO REPLACE IMPORTS 97}

In order to form some judgment of what are the possibilities, however remote they may be, of producing the whole of the food that we buy from foreign countries, we may frame the following estimate, necessarily very approximate, of the amount of extra arable land that would be required in the United Kingdom for the purpose.

TABLE X.-ACREAGE OF ARABLE LAND REQUIRED TO PRODUCE IMPORTS OF FOOD FROM FOREIGN SOURCES

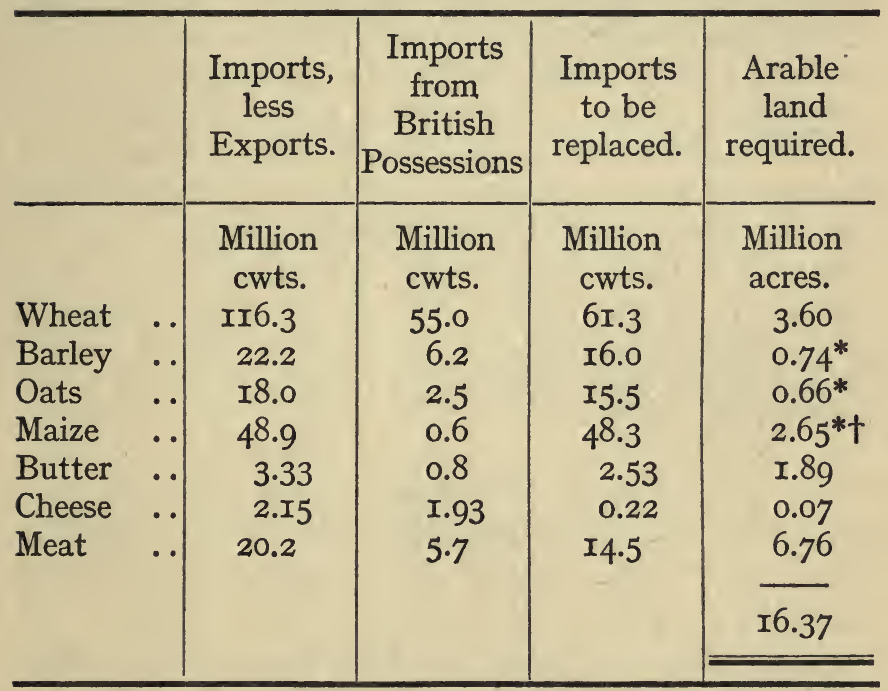

* Assuming that both grain and straw are consumed in place of the imported grain.

t Replacing maize by oats and barley.

The acreage required to replace imports has been calculated on the following basis: The number of units of absolute food (starch equivalents in lbs.) produced by British 
crops per acre, taking the average yields of the last ten years, is as follows: Barley, grain and straw, I,7I6; oats, grain and straw, I,576; roots, 2,4I8; rotation grass, 840 ; permanent grass, 645 . The average for arable land may thus be taken at $\mathrm{r}, 800 \mathrm{lb}$. of starch equivalent per acre. The starch equivalents per cwt. of barley, oats and maize (grain only) are 79,67 and $9 \mathrm{I} \mathrm{lb}$. respectively. $60 \mathrm{lb}$. of starch equivalent have to be consumed to produce $I_{4} \mathrm{lb}$. of live weight increase or $8 \mathrm{lb}$. of meat (average of beef, mutton and pork). This figure is somewhat high, being true for the increase in adult animals, whereas young stock make a bigger increase on the same weight of food. The arable land is assumed to produce $4,000 \mathrm{lb}$. of milk per acre, equal to $150 \mathrm{lb}$. of butter or $350 \mathrm{lb}$. of cheese. A deduction has also to be made for the food value of the separated milk and whey produced as byproducts in butter and cheese making, and also for the straw and the offal obtained with the wheat. Only ro per cent. of the offal is allowed for because the bulk of the wheat is imported as grain ; its offals now come into the country, and only the offals corresponding to the flour imports would be added to the cattle food of the country if the wheat was grown at home.

Thus a total of I6 million acres of arable land would be required to grow the main items of the food we import. Nor would this 16 millions be enough, because when they have been taken from the grass land in order to grow the imports we shall still have lost the cattle food that they were previously producing as grass. A further calculation shows that this I 6 millions would have to be increased to 24 million acres of arable land in order both to replace the imports and maintain the cattle food at present derived from the grass.

This means that nearly the whole of the cultivated area in the United Kingdom, 47 million acres, 


\section{CAN THE U.K. BE SELF-SUPPORTING? 99}

would have to be converted into arable land, though doubtless a good deal less would do the work, because any increase approaching this magnitude in our acreage under the plough would only be attained under such a generally higher standard of farming that the production on all the better lands would be greatly intensified. We are so far from the realization of any development on this scale that even to set down these approximate estimates of how it might be accomplished may seem to be visionary; however, imperfect and remote as they may be, I have thought it advisable to let them stand. So much has been said from time to time as to the possibility on the one hand of rendering Great Britain self-supporting in the matter of food, and on the other of the impracticability of any departure from our present system, that we may as well determine what order of facts we have to face. To produce our own food may be a vision; I would prefer to regard it as an ideal towards which to work, confident that every step we take in that direction is an addition to the strength and stability of the nation.

To return to the more modest programme under consideration, the reconversion of nearly 4 million acres of grass land to arable-the restoration of the state of affairs prevailing in 1872 -it is at least certain that even such a distribution of the land (in Great Britain, I8 million acres of arable out of a total of 32 million acres of cultivated land, or 56 per cent.) by no means represents the limit of possible effort. In France the arable land was, in IgIo, nearly 65 per cent. of the cultivated land; in Denmark, in I9I2, the arable land including the rotation grass was as much as 89.4 per cent. of the agricultural area; even in Holland, with 
its large proportion of polders and wet land, the arable amounted to 40 per cent. of the land reckoned as in cultivation.

There is another aspect of the case to be considered : though the average yield from British land is high compared with those attained in most other countries, it is susceptible of very considerable improvement. For many crops, especially roots, the average yield returned is very far below that which an ordinarily good farmer expects and indeed consistently attains. To a certain extent the good farmers are in possession of the best land, but none the less the bulk of the cropped land will yield much more liberal returns with the use of more fertilizers and more skilled cultivation. It may be calculated that the farmers in the United Kingdom only consume artificial fertilizers of one sort or another at the rate of little more than I* cwt. per acre of arable land per annum; with good farming this quantity could be doubled with advantage, and we might expect to realize from this cause alone ro per cent. increase in the total production of crops. It is not too much to say that if the farming throughout Great Britain reached the standard, not of the best, but of the good farmers existing in every district, there would be an increased production of food of from Io to I5 per cent. without any addition to the existing proportion of arable land.

Denmark has already been mentioned as a country possessing an exceptionally high proportion of arable land, but Denmark is even more instructive as an example of how a country can regenerate its agriculture within a comparatively short space of time. After the disastrous war of 1864 a great national movement 
GROWTH OF DANISH AGRICULTLPE IOP

towards education took place; the results of that movement in the development of agriculture are to be seen in the following figures, the most remarkable feature of which is the way the rate of improvement has been rising in the latter years of the period.

\begin{tabular}{c|c|c|c|c}
\hline Year. & $\begin{array}{c}\text { Total cultiva- } \\
\text { ted area. } \\
\text { I,000 acres. }\end{array}$ & $\begin{array}{c}\text { Corn and } \\
\text { other } \\
\text { Crops. }\end{array}$ & $\begin{array}{c}\text { Rotation } \\
\text { Grass. }\end{array}$ & $\begin{array}{c}\text { Permanent } \\
\text { Grass. }\end{array}$ \\
\hline I87I & $6,4 \mathrm{Ir} 2$ & $\mathrm{I}, 837$ & \multicolumn{2}{|c}{3,575} \\
I888 & 6,829 & 3,997 & 2,265 & 567 \\
I896 & 6,947 & 4,050 & 2,333 & 564 \\
I90I & 6,988 & 4, I09 & 2,293 & 586 \\
I9I2 & 7,289 & 4,522 & I,75I & I,016 \\
\hline
\end{tabular}

Between 1896 and 1912 the proportion the corn bears to the other crops has remained almost constant at 40 per cent., i.e., two straw crops in a five year rotation, but the proportion of root crops has risen from under 5 to over I2 per cent. of the agricultural area.

The effect of the extension of the cultivated area and other improvements is most strikingly to be seen in the numbers of live stock, as follows:

\begin{tabular}{|c|c|c|c|}
\hline Year. & Total Cattle. & Milch Cows. & Pigs. \\
\hline I87I & I, 238,898 & - & $44^{2}, 42 \mathrm{I}$ \\
\hline I88I & $\mathrm{I}, 470,078$ & 898,790 & $527,4 \mathrm{I} 7$ \\
\hline I888 & $\mathrm{I}, 459,527$ & 954,250 & 770,785 \\
\hline I893 & I,696, 190 & I,0II,098 & $829, I 3 I$ \\
\hline 1898 & I, 744,797 & $I, 067,265$ & $\mathrm{I}, \mathrm{I} 68,493$ \\
\hline I903 & $\mathrm{I}, 840,466$ & $1,089,073$ & I, 456,699 \\
\hline 1909 & $2,253,982$ & $\mathrm{I}, 28 \mathrm{I}, 974$ & $I, 467,822$ \\
\hline I9I4 & $2,462,862$ & I, 310,268 & $2,496,686$ \\
\hline
\end{tabular}


Nor has the improvement been confined to numbers and acreage; from the following table it will be seen how the yield of cereals has been raised by selection of better varieties, more fertilisers and improved cultivation :

\begin{tabular}{c|c|c|c|c|c|c|c}
\hline & \multicolumn{2}{|c|}{ DENMARK } & & \multicolumn{3}{c|}{ ENGLAND } \\
\hline Years. & Wheat & Barley & Oats. & Years. & Wheat & Barley & Oats. \\
\hline & Bush & els per & acre & & Bush els per & acre \\
I888-92 & 34.6 & 29.9 & 32.2 & I885-94 & 29.4 & $33 . I$ & 40.6 \\
I908-I2 & 42.0 & 36.5 & $4 \mathrm{I} .3$ & I902-II & $3 \mathrm{I} .8$ & 33.4 & 42.3 \\
\hline
\end{tabular}

The average Danish yield has increased by 24 per cent. in twenty years and now overtops the English, which only increased in seventeen years by 4 per cent., a barely significant figure.

The average annual yield of butter per cow was estimated in I 864 as about $80 \mathrm{lb}$. ; by I 887 it had risen to II6 lb., by I908 to $220 \mathrm{lb}$, and by I9I4 to $229 \mathrm{lb}$. In the competition between herds as to butter production, the tests and observations for which extend over two years, the average production of butter per cow in the four prize winning herds in I897-9 was a trifle over $300 \mathrm{lb}$. per annum; in IgII-I3 in the four prize winning herds it had reached the astonishing average of $445 \mathrm{lb}$.

Naturally this progress in the industry has been 


\section{RESULTS OF NATIONAL EFFORT I03}

attended by an increase in the numbers of people " living by agriculture," as follows:

\begin{tabular}{|c|c|}
\hline Year. & Number of Persons. \\
\hline & \\
I870 & 788,735 \\
I880 & 888,931 \\
I890 & 882,336 \\
I9OI & 971,894 \\
I9II & 969,227 \\
\hline
\end{tabular}

Now all this remarkable advance within half a century has been achieved deliberately by the educational activity in its widest sense of the State, working it is true on a favourable soil-the temper of a people who were rousing themselves to shake off the effects of defeat. In the face of these figures, which cover the period during which as the records show British farming was declining, will anyone be found seriously to maintain that the stimulus of the State cannot be applied to agriculture and that our farmers know how to make the best use of the land when left to themselves? 


\section{CHAPTER VI}

THE DEPENDENCE OF ARABLE FARMING UPON PRICES

THE degree to which arable farming may be extended or even maintained must, however, be limited by two factors-the average price of the chief agricultural products, wheat and meat for example, and the price of labour. We know that at the scale of prices prevailing during the years immediately preceding the war, with wheat at about 35 s. per quarter, arable farming was distinctly prosperous, so much so that it might with profit have been extended over at least as much land as had been under the plough in 1872 . If we further take into account the possibilities of diminishing costs by the greater use of machinery and improved organization, as on the suggested large scale farms, "we might expect that the land could pay wages at rates comparable to those received by labourers in other industries, and yet provide a reasonable return for capital and management. But if prices again go down to the level that was reached in the 'nineties and wheat has to be sold at well under 30 s., all these prospects vanish.

With wheat permanently at $25 \mathrm{~s}$. and other produce to correspond (a rough equivalence will always be maintained because wheat can be used to replace other feeding-stuffs), no available skill or organization can keep under arable cultivation any but the choicest of 
British soils, and at the same time pay the labourers 2Is. a week. Rents might even be extinguished, and yet much of the land would fail to pay its way under the plough; the mere cost of cultivation would swallow all the receipts. What the limiting price is for the various soils and climates to be found in Great Britain cannot be exactly estimated from the data at command, but we have as a general guide the fact that after wheat had risen to 30s. and over, land in England still continued to go down to grass, even though wages were much below the 2Is. rate. With farming what it is and rents at their present level (equivalent to about 5s. a quarter on wheat) the farmer considers that he will make better profits by putting down much of his land into grass. It is true that substantial reductions in cost might be effected by more skilful and wholesale working, but the general principle remains untouched that on land of any given quality there comes a point when arable cultivation cannot be maintained because of the smallness of the returns for the produce and the comparatively high proportion that labour bears to the cost. An acre of arable laifd may produce twice as much as an acre of grass land, but the labour needed is at least ten times as great ; at some stage in the relative prices of labour and produce the grass land must become more profitable than the arable. Nor will high farming to secure a greater output per acre remedy matters; we are sufficiently near to the limit of production for the law of diminishing returns to come into play. The last quarter is always the most expensive to produce in labour as in other expenditure, and Sir John Lawes' old maxim is true, that high farming is no cure for low prices.

The small holder cannot solve the difficulty; as a H 


\section{Io6 DEPENDENCE OF ARABLE FARMING}

rule he evades the intensity of foreign competition by producing only vegetables, fruit or milk, which are naturally protected by the necessity of freshness and the relatively heavy cost of freights. But these markets cannot be indefinitely extended. Milk is already wholly produced at home; vegetables and fruit imported from foreign countries only amount to $£ 6$ millions in value, representing the production of perhaps 300,000 acres of land, which leaves the main business of agriculture untouched. Moreover, it is not be expected that the small holder will be left in sole possession of the fruit and vegetable market ; the more unremunerative ordinary arable farming becomes, the more will the large producer tend to turn his energies into channels that still offer the prospects of profit and where his powers of wholesale working will enable him to compete successfully with the small holder. In fact, both small and large farmers are in the same boat: the returns of both depend upon prices that are fixed in the main by foreign competition to supply the staple articles of production-wheat and meat, because these prices in their turn determine the extent of the internal competition to secure a share in the production of the articles that are naturally protected, like fruit and vegetables and milk.

It follows from this argument that if the State, for reasons of national security and insurance against the effects of war, must obtain a larger production of food at home and greater employment upon the land, which can only be effected by an increase in the area of arable cultivation, it cannot leave agriculture to the unrestricted play of foreign competition, but must ensure that the farmers' returns do not fall below a 
certain level. This takes us into the very debatable land of duties and bounties. Both may be regarded as economically unsound in the sense that they would make the nation as a whole pay more for the food it consumes than it would if left free to purchase in the open market that exists during times of peace. Both benefit one class of producer at the expense of the whole community of consumers, both carry with them certain incidental dangers such as the encouragement to the formation of rings and trusts, the removal of the stimulus of competition, etc. We may concede the validity of all the standard free trade arguments, grant that the maintenance of agricultural prices is likely to be attended by some expense to the nation, and yet accept that cost as a part of the national defences, as necessary and as immediately unremunerative as the Army or the Navy. It is more than possible that the need for duties or bounties will not arise; before the war it seemed likely that the rise in fundamental food prices would be maintained for some time to come, and they were high enough to sustain much of the development of agriculture that we are seeking. But it is difficult to prophesy what prices are going to be when peace comes again; even the most experienced economists differ in their opinions. From one point of view the great destruction of men and materials that has been wrought must diminish production and so raise prices; on the other hand, it may be objected that the destruction has been wrought in the old countries which were buyers. The new countries which are the great producers of cheap food are untouched, and have been even stimulated by the needs of the old world; they will still have their produce to sell in a market 


\section{I08 DEPENDENCE OF ARABLE FARMING}

diminished both in numbers and purchasing power, so that the price of wheat and meat will fall.

Let prices be what they will, the uncertainty is almost as bad for development as actual low prices; the British farmer, if he is to plough up grass land on any considerable scale, must have some security as to the basis on which he can conduct his business.

Assuming, then, that the State decides to bring about a greater production of food at home, it must begin by either stabilizing the prices of agricultural produce, or ensuring in other ways an adequate return to the farmer, at any rate during the critical years while the change is being made and men are being accustomed to new methods. On the whole a system of bounties on production seems to be preferable to one of duties on imports; the country is surer of a return for its outlay and knows exactly what its policy is costing, and the consumer does not get the price put up artificially against him by the operations of a ring formed behind the shelter of a tariff wall. One proposal is that put forward by Lord Milner's Committee on Food Production in I9I5-to fix a standard price for wheat and to pay to the farmer for each quarter of marketable corn the amount by which the average official price for the year falls below the standard adopted. The only new machinery required would be the attendance on due notice of an excise officer or even a policeman when threshing was taking place in order to register the amount of head corn passing through the machine, for which a certificate would be given to the farmer. The farmer would preserve his certificates and claim on them at the end of the year should the declared average price of British corn for the year fall below the 


\section{A GUARANTEED PRICE OF WHEAT IO9}

fixed standard. This procedure would get over all difficulties caused by varying quality in the farmer's output; he would still try to make the best price he could and get all advantages of growing seed corn and the like, while the farmer who turned out his wheat in bad condition would suffer the loss consequent on its realizing less than the average price for the year. It would probably be sufficient to confine the bounty to wheat. In the first place it is the production of wheat we most desire to stimulate. Wheat cannot occupy the whole of the arable land, and a bounty on wheat would act as a general bounty on arable farming. If, however, standard prices were similarly fixed for oats and barley, arable farmers would be assisted in all districts, for the growth of one or other cereal forms part of every system of arable farming. Some danger might be apprehended lest farmers should turn their attention entirely to corngrowing and not maintain enough stock to make the farmyard manure required to keep their land in condition. But few men would be able to embark upon continuous corn-growing on Mr. Prout's system, which depends upon a convenient market for straw; the majority would need to convert their straw into manure, and there is no way of doing that except by cattle. It is possible that there would be less of the intensive cattle feeding that is practised in Norfolk and the other bullock-fattening counties, but it has been for many years an uneconomic process ; if the cattle are managed primarily as producers of manure from straw without trying to enrich it so much by the heavy consumption of cake, there may be less beef for sale but the farmyard manure that is wanted to keep up the humus in the soil will still be made. 


\section{IIO \\ DEPENDENCE OF ARABLE FARMING}

Another plan which is free from some of the objections to a bounty on wheat or cereals generally would be to pay a certain sum annually on the land brought under arable cultivation over and above that which was so used at the close of the war. This plan has the advantage of paying only for what was obtained-the extension of the arable area. It would be more of the nature of a bargain between the State and the farmers to secure a system of cultivation which the State desires, but which the farmer might otherwise not consider profitable to himself. The amount to be paid could be adjusted to an equivalence with the other proposal of a guaranteed price for wheat. For example, if the State guarantees a minimum of $40 \mathrm{~s}$. a quarter for wheat, this would amount to a bounty of $£^{2}$ per acre when the price of wheat fell to 3os. As wheat would not on the whole be grown more often than one year in four, a bounty of Ios. per acre on the extra arable land obtained would then be equivalent to the guaranteed price of 40 s. for wheat. It would even be possible to fix a sliding scale of payment varying with the declared price of cereals. This proposal would require rather more administration than a guaranteed price for wheat, as it would involve a more exact record of each farmer's cropping than at present exists; but the difficulties can be overcome, and more exact statistics of the cropping of the land in the country are themselves worth paying something for. Arrangements could be made whereby the farmer could anticipate the payments for some years by obtaining them in the form of a loan which would give him the capital he needs for the extension of his arable cultivation. This plan has the great advantage of fixing within small 
limits the commitments of the State each year; it would represent a payment for services rendered, and it would not give any unearned assistance to the farmer who finds his arable land remunerative at the pre-war scale of prices. Again, it would leave the farmer free to grow whatever arable crops were most useful to his business ; the dairy farmer, for example, would be encouraged to feed his cows upon cultivated land and not depend upon cheap grass. If the nation obtained the extra arable land, though it was normally employed in producing the more remunerative milk and meat, in time of war it could be at once sown with wheat. A sliding scale of payments would further get over the objection that attaches to paying any bounty when prices rise to such an extent as to render the arable farming profitable without any assistance. It would be an insurance against the occurrence of conditions that drive the farmer back to cheap grass land farming, and would give him the security he needs before embarking upon new methods of cultivation.

The fundamental objection to bounties or duties alike is that some of the State's expenditure goes into the pockets of men who have done nothing to earn it. Consider in the one case the man who can make wheat-growing pay at present prices (or rather at the price prevailing before the war), and has in consequence as large an acreage of arable land and perhaps of wheat itself as his land will stand. A bounty will be so much pure gain to him; the State may have to pay him a considerable sum in any one year for which it does not get a single extra quarter of wheat. Presumably the extra profit would soon be swallowed up by a corresponding increase of rent; but whether the 


\section{II2 DEPENDENCE OF ARABLE FARMING}

farmer continues to draw the bounty or it is passed on to the landlord, the prime fact remains that the State pays something for which it receives no return. Indeed, the whole of this fundamental objection to bounties or duties turns on the question of rent. If certain land can only be brought under arable cultivation by the operation of bounties or duties, all the land that had already been profitable as arable receives an unearned increment which in time reaches the landowner, because as the profit-earning power of the land is enhanced its letting value will rise correspondingly. Rent, in fact, represents the margin between the value of the produce and the cost of production in its widest sense, including the remuneration the farmer expects for his management and the use of his capital. The changes in rental may lag behind the changes in the value of the produce, but ultimately the adjustment will be effected under the pressure of the competition for the good land. Here is the prime difficulty attaching to either protective duties or bounties on agricultural production, that land is of unequal value and that the owner eventually receives all the benefit when the land is capable of producing at a profit without assistance.

I am only aware of one method of meeting this objection-that the State should become the universal landowner, and so get back any increment in value brought about by its own action. The State might, in fact, give the landowner security for an annual income equal to the present rental and take itself the fluctuations in value brought about in one direction or other by its own action, by foreign competition, or by the growth of the community. There is nothing essentially confiscatory or unjust in such an arrangement, and it 


\section{EFFECT OF BOUNTIES UPON RENT II3}

would be possible to leave to such landlords as desired to retain their leadership the power to control and develop their land. The State, however, would then be able to strike a bargain and receive payment for such additions to the value of any given area of land as were brought about by the imposition of duties or the award of bounties. With this security the State would be able to embark upon any policy designed to bring about the more intensive use of the soil without saddling itself with the expense of rewarding the owners of such land as required no artificial stimulus to bring it into the system of cultivation desired. The State could sum up the cost of its policy, knowing that it would be paying only for what it effected, and could form a judgment as to whether the benefits accruing, indirect and prospective, were likely to be equivalent to the direct expenditure to be incurred.

It is not worth while discussing in detail so remote and controversial a proposition; it may well be that the need of considering it will not arise, because agricultural prices after the war may remain at such a level as will pay for the extension of arable farming that is desired. But it is necessary to insist upon the fact that the extent of arable farming is dependent upon the prices for produce; that if the State for its own safety must obtain a maximum of arable land, it may find it necessary to extend some measure of assistance to the farmers, in which case it could secure itself from unnecessary loss by at the same time taking over the land with any increments in value due to its own action.

This much is certain: that in the critical period of the reconstruction of our national economy, the State 


\section{II4 DEPENDENCE OF ARABLE FARMING}

cannot afford to allow the use to which its land is to be put to be merely dictated by the prospects of individual profit. The most convinced free trader must admit that his principles cannot have free play during the war, because the conditions on which they are based no longer exist, and as the state of economic dislocation persists for long after the war, the argument that any proposals to give direct State assistance to the particular industry of agriculture must be dismissed because such action is contrary to free trade principles, is beside the question. It is a valid principle that a family should live within its income, but when it is faced with the necessity of rebuilding its house after a fire, it may have to put that principle aside in order to get a roof over its head.

What are the alternative prospects if we leave things to take their chance? The future cannot but look dark, the prospects of the course of trade cannot but appear uncertain ; what is sure is general impoverishment and heavy taxation. The wisdom of the ancients will counsel the farmer to sit tight and reduce his commitments. He has before him an excellent opportunity of playing for safety by laying down his land to grass, for thereby he can reduce his capital at risk, and can curtail his expenditure without greatly diminishing his profits. While many farmers accept the rise in wages brought about by the war as a permanent change, others anticipate that the disbandment of the army and the industrial depression consequent on the general poverty will result in considerable unemployment, so that wages will come down again to their former level or somethirg less. Then, if prices serve, the cautious farmer can resume his arable farming on the old basis of cheap labour without 
troubling himself to reduce costs by the application of machinery and improved methods. But his first impulse will be to make himself secure by an extension of grass, as many farmers are doing to-day, and he will pick up the threads slowly and carefully; he will make very sure that prices are going to be good enough and labour cheap before he moves even back to his old position. The experience of the last fifteen years teaches us that the farmer who has once got his land down to grass is very cautious about breaking it up again. If prices fall below the pre-war level we shall see England steadily moving towards the condition of universal grazing and depopulation that characterize large portions of Ireland.

Nor is the farmer to be blamed if he adopts a conservative policy. Apart from self-interest, he is told that he can best serve the needs of the country by making his farm pay. The State has taken no particular care of him in the past, and if he sees in the period of approaching reconstruction that the State is again indifferent to agriculture and content to let it go its own way, he will be more than justified in taking his own line and making use of his land according to his lights. He asks for a lead, but mere appeals to his patriotism and advice from the chair will be neglected; he will judge of the country's needs by the effort the country makes.

Meantime, what of the men who cannot wait? Are we prepared to accept a widespread emigration, with the corollary of heightened taxation on those who remain and a diminished earning power of the community? We do not wish to deprive the Dominions of a single man who can earn a better living there, remem- 


\section{II6 DEPENDENCE OF ARABLE FARMING}

bering how this war has shown us that their men and our men are one people. But English land offers opportunities as good or better than the land beyond the seas; it also can carry men if only equal access is given to it. Are we, again, prepared to face the discontent of the unemployed and the scantily-paid, who see the land comparatively unused and earning profits only for the few? A good many men who have served in Flanders or France have been led to think about the universal tillage they see there, and to wonder if English land is not amenable to similar development. Such discontent may easily lead to violence, or at least to hasty legislative action that will have small regard to the interests of owners and present occupiers. Now is the time for preparation; the State must frame its policy before the pressure comes upon it.

I submit that such a policy must be based upon two fundamental propositions: first, that the land must be made to produce more food for the nation; secondly, that the labourer must be paid a living wage. To effect this we cannot trust to private enterprise alone, i.e., to the prospects of individual profit. We have every reason to conclude from experience that arable farming on which increased food production depends may not lead to increased profit, farmers and the land system being what they are, and considerations of personal profit alone make in general for low wages, however much the few may perceive that the ultimate efficiency of the labourer is conditional upon his being adequately paid.

The State must intervene to bring about progress and not decay, and to secure that the opportunity the national crisis affords is turned to national uses. We 


\section{ACTION OR INACTION}

cannot tolerate in this connection the argument that any action of the State is so sure to be mistaken and to be mismanaged in the actual undertaking that we had better let things alone and trust to private enterprise. The State may seem to have made blunders enough in the conduct of the present war to justify such pessimism, but it has been this very negation in the past of the duty of forethought and the value of deliberate preparation that has brought about our difficulties. We have trusted to individual enterprise and self-interest as the only principles of action; let us at least acknowledge their failure and resolve to take thought for the future. 


\section{CHAPTER VII}

\section{WHAT ACTION IS PRACTICABLE}

BuT apart from these general considerations, what is the immediate programme that can be put forward with any hope of realization, a programme that neither calls for too violent an action by the State nor expects too immediate a reform on the part of the farmers? We must not hope for any rapid change, simply because we are limited by the numbers and qualifications of the men actually in occupation of the land; we can neither add to them nor replace them all at once. To get another million acres of plough land out of the present race of farmers will represent an enormous advance, as much as we may hope to attain while we are preparing for the more drastic action-the newer men and methods by which alone can be realized the five to ten million additional acres that are necessary to the safety of the State. We may give ourselves a generation perhaps in which to work to this end; for that space of time at least we may expect that peace will be ensured by the exhaustion produced by this war and by the remembrance of the suffering it entailed. We have, then, to shape our policy immediately to meet the dislocation and relieve the unemployment consequent on the disbandment of the armies, and so prevent the permanent loss of men to the country by emigration; 


\section{AN IMMEDIATE BOUNTY}

then more gradually to effect a progressive intensification in our general treatment of the land.

The immediate situation is best met by the guarantee of either a maximum price for wheat or a payment for the extension of the arable area for a period of from five to ten years. This will give the farmers the confidence they lack, it will arrest the movement towards laying down land to grass and will secure straightway an increase in the demand for labour; of itself it should bring about the ploughing up of another million acres of grass land, which would provide employment for 20,000 to 30,000 more men. The offer of some form of assistance should precede any other measure ; it is necessary to furnish the stimulus required to make the farmers set about the prompt extension of their business. If it is not promised even before the war ends, if we wait to see how the situation develops and to ascertain the extent of the unemployment, the opportunity may well be lost, for the farmer will wait even longer in order to make sure of his prospects. Moreover, the farmer can never begin to develop his business at any given signal. If he is going to plough up grass land and crop it in the following season he should begin to lay his plans in June; then the old grass land that he can get broken up by steam or motor in July or August will be fit for wheat, oats or potatoes. Winter-ploughed land will in many cases require a summer's fallowing before it can profitably be put under crop, and this is particularly true of the indifferent and weedy old pasture that is most in need of breaking up. At the outset the question of how the State should deal with the landowners in order to prevent the assistance given going simply into their pockets as increased rent, may safely be left over until 
it is seen how prices are tending and what the State is getting for its outlay. The guarantee is avowedly a temporary measure to secure an immediate increase of employment and to give the farmer confidence to develop his business. But the quid pro quo upon which the State must insist as a sufficient return for the moment is a minimum wage for the labourers in any districts in which an attempt is made to return to the low pre-war rate of payment. Without better wages and better housing, the more enterprising men will certainly leave the country, and if we wait for the " haggling of the market" to bring wages up to the proper level, we shall lose the men. The better farmers know already that wages must rise or be maintained at war level. Many of them have in the past been paying such wages almost by stealth; but many will put up a long, if losing, fight against them, because they have always before them the alternative of resorting to grass land without much personal loss. It may be argued that a minimum wage will be construed as a standard wage, and that the labourers will suffer thereby in districts like the North-Eastern Counties of England or Scotland, where wages before the war were above any minimum that is likely to be fixed. But the farmers in those very districts are already convinced of the necessity of good wages and of their value; they will have to compete with the industries for their men after the war as before. It is only necessary to protect the labourer in certain districts where agriculture had become practically a sweated trade because of the lack of other outlets for men. The farmer in those districts can equally turn higher wages to profit if he is checked in the attempt to utilize any temporary pressure of 
unemployment after the war as a means of getting back to the old scale. Success in such an attempt would not be to his permanent interest; he would only finally drive the men off the land and progress further in the vicious circle of having to lay down land to grass because men were scarce. The mere prospect of a minimum wage tribunal for particular districts might very well ensure that it would have no work to do. As the State is going to offer its guaranteed price, not for the sake of the farmers or the landowners but in the interests of the nation, it must ensure as part of the bargain that the long-suffering agricultural labourers obtain their opportunity of a decent living. If it secures better wages for the labourers the State will have got some return for its guarantee, and the question of rents and tenure can well stand over until it is seen how the situation is developing.

What would such a policy cost and what would the State obtain in return? Let us assume that after a time the arable land was increased by six million acres, and that the State had guaranteed a bonus of ten shillings an acre on all this increased arable land, then the annual expenditure of the State would amount to $£ 3$ millions a year. On the increased acreage of arable land the whole of the wheat required by the country could be grown; e.g., a declaration of war in August, the usual date, could be followed by the sowing of seven million acres of wheat for which there would be land ready. Meantime there would be that year's harvest in hand for the immediate needs of the country, and if only one quarter of the increased arable acreage had been sown with wheat in the previous year, the country's stock to meet the first shock of war would 
amount to 40 per cent. of the whole requirements before the new crop was ready. We are assuming that under peace conditions the new arable land would be used in the ordinary way for general crops, meat and milk rather than specially for wheat, its normal output would amount to about $£ 42$ millions per annum against less than half that amount when under grass. Taking the additional output of food produced at home instead of imported at a value of $£ 25$ millions, then on the basis of what has already occurred (p. 6) -that in the first year of war the cost of imported food is increased by 50 per cent., we should be producing at home what would cost the country $£ 37 \frac{1}{2}$ millions in war time, a saving of $£ \mp 2 \frac{1}{2}$ millions. In each year of war there would therefore be saved the nation's expenditure on the bounty for four years, and this saving would come at the time when it was most needed to preserve the nation's credit. Considering this, and considering also the saving effected by the reduced pressure on freights, it is not too much to expect that the saving during a year's war would be equivalent to six years' peace expenditure. It may be questioned, moreover, whether the annual expenditure of three millions is not largely made up to the State in other ways. It would call into existence an extra $£ 25$ millions worth of food, say $£^{20}$ millions after deductions for manure, machinery, etc., have been made, all sheer gain, because agriculture is the most purely creative industry that exists. It would further provide employment for at least I50,000 men, who ex hypothesi would not be withdrawn from some other form of labour like manufacturing, but would form an addition to and a support for the manufacturing population, because the United 
Kingdom is still a country with a surplus population that finds its outlet in emigration. In one way or other, after all the exchanges have been effected, it may be expected that a proportion of the $£ 20$ millions of created wealth would find its way back to the State in the form of taxation, and so go indirectly to reduce its expenditure on the scheme. If instead of six we postulate an extra ten million acres of arable land, the annual expenditure would rise to $£ 5$ millions; but we should have gone a long way towards assuring the independence of imports of food in time of war, and who will say that such security had been dearly bought at a cost equal to that which is annually expended on the construction and maintenance of two battleships!

- The other immediate step that should be taken, and again preparations should begin before the war ends, is to have in hand schemes for the reclamation of all the waste land in the country that offers any prospect of profitable development. The schemes will naturally vary in their commercial aspects; those that are reasonably certain of success would be taken first, leaving those on which the immediate return is more doubtful to be started only if the pressure of unemployment becomes so great that something in the nature of relief work must be provided. At its worst such work is creative and does result in some continuous revenue for the State-in increased employment and increased production of food with all the industries that follow in its train, so that the criterion of profitable development can be very liberally interpreted. The great value of reclamation work lies in the large.numbers of the men, over and above the men to be permanently settled on the land won, who can be employed 


\section{I24 WHAT ACTION IS PRACTICABLE}

for a year or more while the reclamation process is going on and until the industries have time to readjust themselves to the new conditions. The necessary preliminary to serious work in the way of reclamation is to give the State power to take over whatever areas of waste and undeveloped land it needs, by some process more rapid and more equitable than the cumbrous machinery of the ordinary compulsory purchase clause, which puts the State at the mercy of a court of arbitrators who have been brought up to regard the monopoly value of land as sacred and the need of the public for the land as the chief factor in making up its price. For this purpose the State should have the same immediate powers as it possesses under the Defence of the Realm Act, and the basis of compensation to the interests concerned must be the loss they suffer by being deprived of the land, not their prospective gain whenever some better use can be found for it.

In these two ways we may hope to deal with the urgent problem of unemployment after the war; for the future development of the land we must begin with a policy of free experiment. A few people who have studied the question may be convinced of the economy of the large industrial farm and of the opportunity it affords for the heightened utilization of the land and for improving the conditions of employment, but the case for this method of working cannot be regarded as demonstrated at large. This statement is equally true of the smallholding colony worked on co-operative lines; their practicability has still to be proved. Let the State, then, set on foot a limited number of each of these ventures on different classes of land and in different parts of the country; in a few years it will be possible 
to estimate their chances of success or failure and their relative value as a means of bringing the land into a higher pitch of cultivation and of providing a career for the cultivators, whether as masters or men. Moreover, these ventures, if they do nothing else, will provide some definite concrete information as to costs of production on land of different types and the returns that labour, management and capital respectively may expect. Who can say on how much land in the country wheat will pay at $30 \mathrm{~s} ., 35 \mathrm{~s}$. and $40 \mathrm{O}$. respectively? At present figures are so scarce, so conditioned by the personality of the farmer, that our arguments are unsubstantial, our basis for State action too speculative. We are faced by the broad fact that the present occupiers of the land of the country consider that only 42 per cent. of the cultivated land of England and Wales is fit for arable cultivation. The statesman who regards such a result of leaving matters to private enterprise as a danger to the Nation must have more facts before he or his representatives are in a position to say to any individual: "Your way of dealing with the land is mistaken; you can make it yield so much more with due profit to yourself; if you do not make a move in that direction we must in the general interests of the nation remove you from the land." No one wants to use compulsion now or to threaten the existing occupiers of land, if for no other reason than that the State is not at present in a position to replace them with anyone better. But the implied threat must be there if the farmers do not respond to the assistance and the opportunity accorded to them. The State must have the arable land and will prepare to obtain it in its own way.

Procedure of this kind under the stress of anything 


\section{I26 WHAT ACTION IS PRACTICABLE}

less than actual war can be denounced as confiscation and tyranny; but we are proposing to prepare against war, and in any case we can be very sure that in the actual working matters would be made easy for an existing occupier, and that his weaknesses will be very tenderly handled by any tribunal sitting in judgment upon him. The conception that a man owes responsibility to the community for the way he conducts his business is too novel to override with any haste the accepted opinion that he may do what he likes with his own.

Meantime, in the light of the figures provided by these experiments and the trend of agriculture under the suggested bounty on production, the statesman can begin to frame his permanent policy for agricultural development and the national defence thereby. He will be able to estimate how much land in the country can be put under the plough, what proportion of the nation's food can be looked for at home, what the cost of pursuing the policy up to a given point is like to be. He will have time to form a reasoned judgment on the big questions of the ownership and tenure of the land, whether the State must resume the ownership as an offset against its bounties or as essential to its control, whether compulsion is necessary to enforce the desired standard of farming and employment, and what form the tribunal shall take that has to decide whether an occupier is farming properly or whether he should be dispossessed. These are or will become urgent questions, but they are not to be attacked hastily and more data are desirable before decisions are taken. 


\section{CHAPTER VIII}

\section{SUMMARY AND CONCLUSION}

THE argument set out in these pages may now be briefly summarized :

I. In the interests of the nation as a whole it is necessary to grow at home a larger proportion of the food we consume: (a) as a national insurance in time of war; $(b)$ to develop our internal resources and reduce our foreign indebtedness, a matter which becomes of greatest moment in war time; (c) to increase the agricultural population as a specially valuable element in the community.

2. These objects can only be attained if more land is put under the plough. Land under arable cultivation produces nearly three times as much food as when under grass, and employs ten times as many men.

3. Some action by the State is necessary in order to secure any considerable ploughing up of grass. The farmers are distrustful of the future both as regards the prices of produce and the cost of labour. Even in the years immediately preceding the war, when prices were high enough to make arable farming really profitable, they preferred the safer if smaller returns on grazing and were still laying down land to grass. This process is likely to continue after the war while uncertainty prevails as to the course of prices and of wages. 
4. Five methods are outlined for obtaining a more intensive cultivation of the soil and providing employment upon the land. IThese are the establishment of large industrialized farms working on a considerable area with all the economic advantages of organization and scientific management, the establishment of colonies of small holders linked together by a co-operative organization, the intensification of the methods of existing occupiers, the reclamation and settlement of waste and undeveloped areas, the establishment of certain subsidiary agricultural industries.

5. If the arable land was increased to the area it occupied in 1872 , by about 4 million acres, and chiefly devoted to wheat, the amount of wheat grown in the country would be raised to about 59 per cent. of our total requirements, and at the same time our production of cattle food would be increased rather than diminished. As British Possessions already send us wheat to the extent of over 30 per cent. of our requirements, all the wheat we require to within Io per cent. would be produced within the Empire. This extension of arable land is still below the limit of what is possible; moreover, a further increase of production is easily possible by the intensification of our existing methods of cultivation and manuring.

6. The commercial success of any scheme for the extension of the arable area must ultimately depend upon the prices that rule for agricultural produce, i.e., upon the intensity of foreign competition. If the State decides that such an increase is necessary in the interests of the national security, it may be driven to adopt some system of bounties or protective duties in order to keep the returns to the farmer up to such a level as will allow 
of agricultural development. This raises the difficulty that the benefits conferred by the State would in time be passed on to the landowners in the form of increased rent. The only final solution of this difficulty is for the State to become the ultimate landowner.

7. The problems of finding employment and attracting men to the land that will press at the close of the war can be met, in the first place, by giving a bounty on arable farming by guaranteeing either a minimum price for wheat or an annual payment for each additional acre put under the plough. This will give farmers confidence and secure an immediate extension of the arable area with a corresponding increase of employment. As a quid pro quo the State should fix a minimum wage for labourers. Preparations should also be made at once for a programme of reclamation of waste land, which would find employment for large numbers of men temporarily and for a proportion of them permanently.

7. A limited number of large industrial farms and of co-operative colonies of small holders should be established in order to test their relative values for dealing with the land intensively and to provide trustworthy data on which the future land policy of the country could be framed.

I may finally be allowed to urge that these proposals are not put forward in the interests of the agricultural classes as such, nor in those of any particular party within the nation. It is no part of my purpose to push the claims of an agrarian party pursuing its own ends under the cloak of the national welfare. I doubt if such a party has ever existed in this country, however much individuals may have been clamorous for the protection 


\section{I30 SUMMARY AND CONCLUSION}

of their own interests and have deceived themselves into thinking that their own well-being was identical with the general good. But the countryman has always had a case when he has fought against the neglect of agriculture during the last sixty years or so, and his main thesis has been true that a country is weakened by allowing its rural population to decay and by becoming parasitic upon other countries for food. The extent and dangers of this weakening is only now being revealed to us by war. Nevertheless, there is no reason to suppose that the reforms I have suggested would be desired by or would be even particularly acceptable to the agricultural community - to the existing farmers and landowners, at any rate. There are other reforms they would ask in preference, other changes more to their personal interest. Indeed on the whole the presentday farmer would rather be let alone; he is making a living and is often doing very well as things are; the best he would ask of Government is not to interfere with him nor disturb the conditions to which he has adjusted his business. Nevertheless, if landowners and farmers see that the State is in earnest to effect a reform in agriculture, if the nation is ready to make some sacrifice in order to develop the resources of the land and to make it play its part in national economy and national safety, they may be counted upon to respond. The war has at least heightened the sense of national service; we all know that a great effort at reconstruction is before us, and the agricultural portion of the community, no less than any other, is prepared to subordinate its immediate interests if it is called upon to share in the rebuilding of a well-knit fabric of the nation. 


\section{SUMMARY AND CONCLUSION I3I}

I have no party nor separate interest to promote, but I have come to know the face of my own country as few men have been privileged to do. It is out of my love for its well-laboured soil, my hatred for the neglect and waste that deface it, and my faith in the vitality of the people who live by it, that these proposals spring. 
㝕

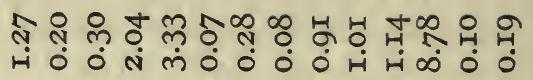

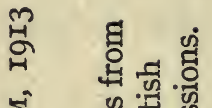

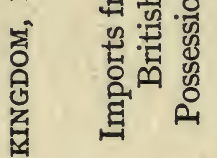

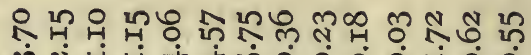
कु

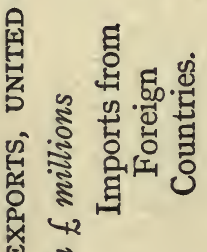

ํํำ สั่

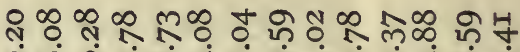

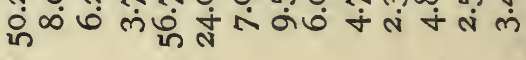

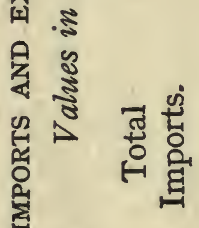

宾

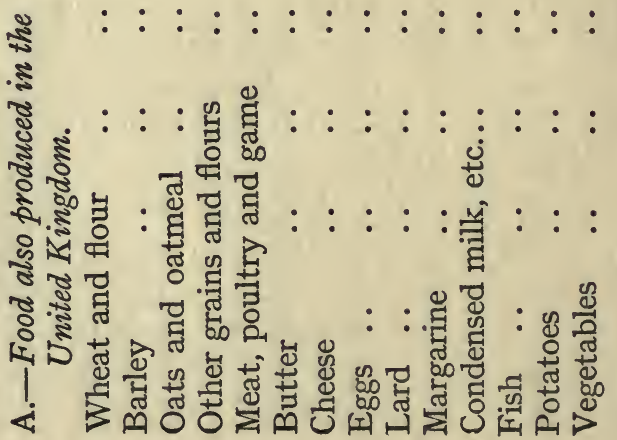




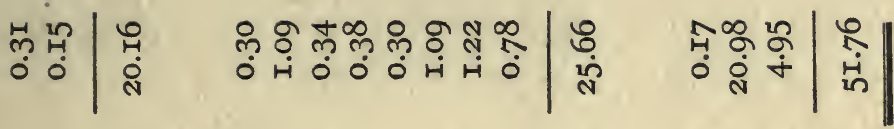

$:: \quad:$

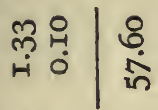

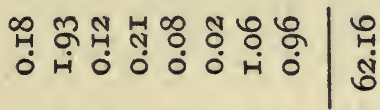

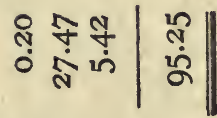

: : :

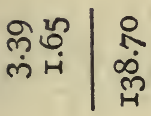

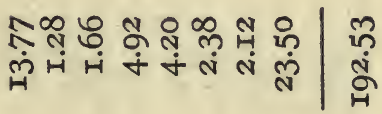

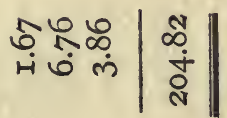

: : :

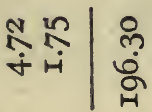

苗

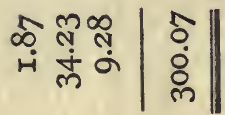

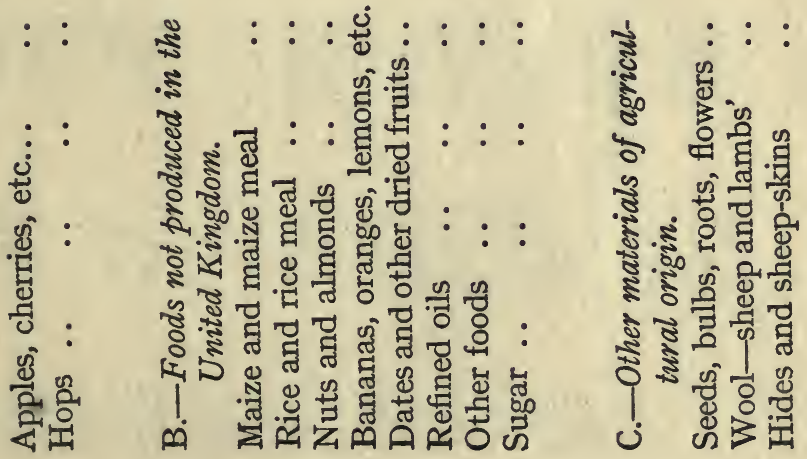




\section{APPENDICES}

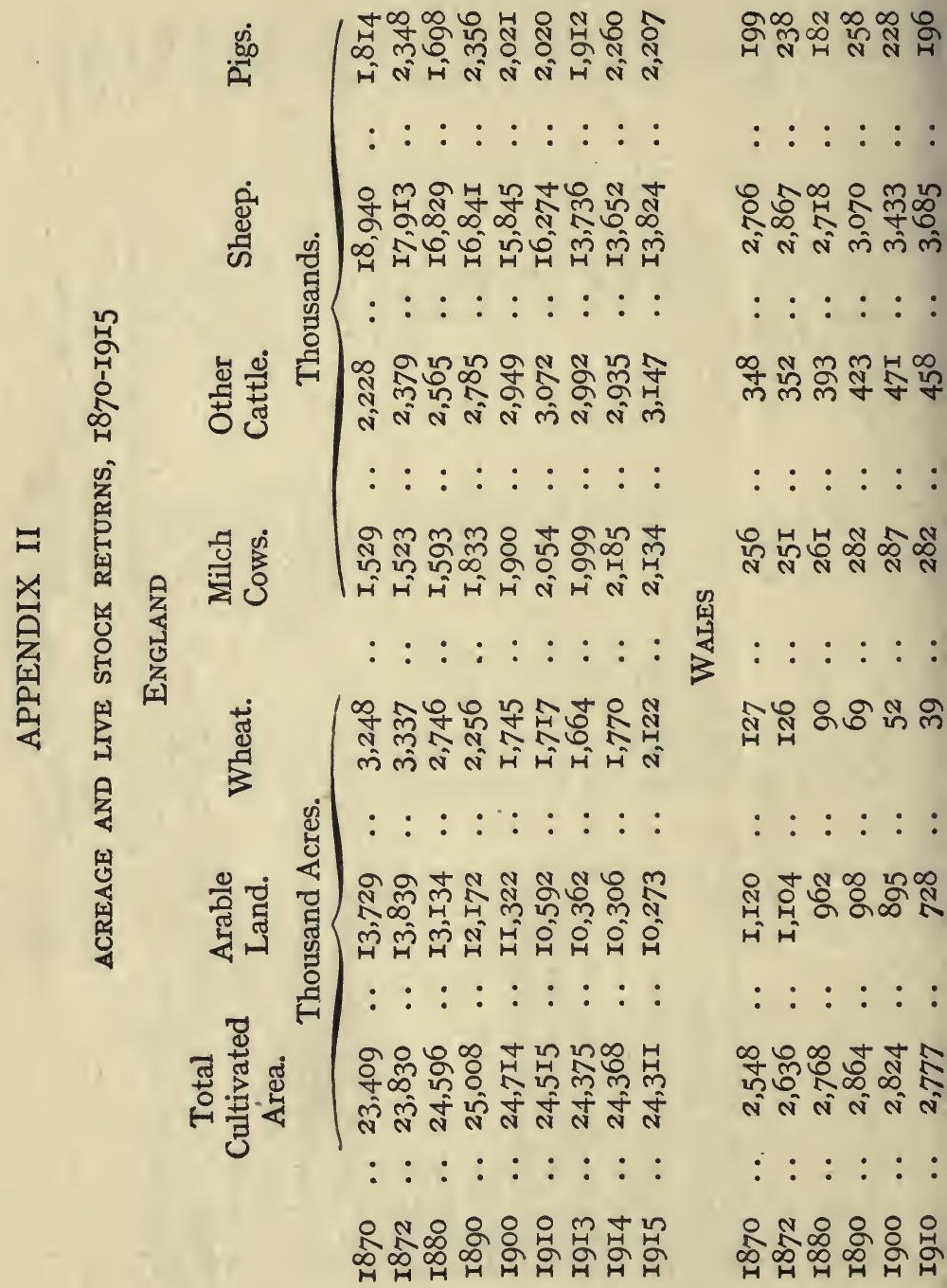


HूN

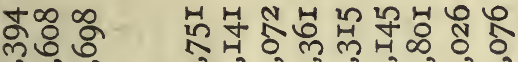
ले ले बिस

母ำ

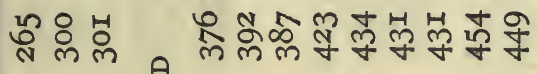
m m ํํำ

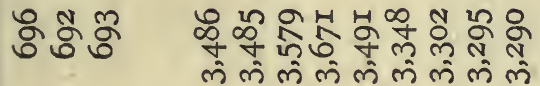

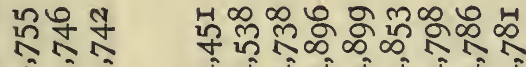
4.

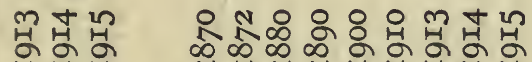

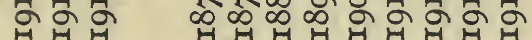

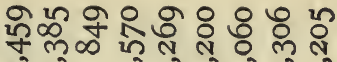

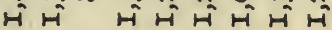

8

. 9

(4)

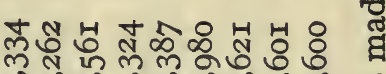

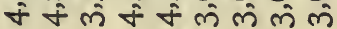

तु

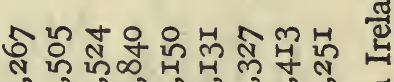
ले ले ले ले ले ले ले ले

요

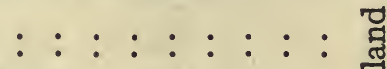

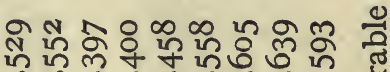

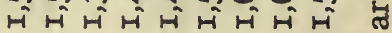

Ф)

o $m: 0$

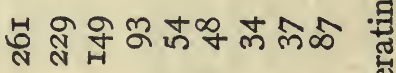

ง $2+*$ \%

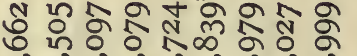

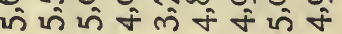

기요

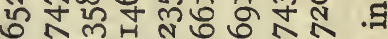

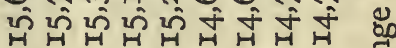




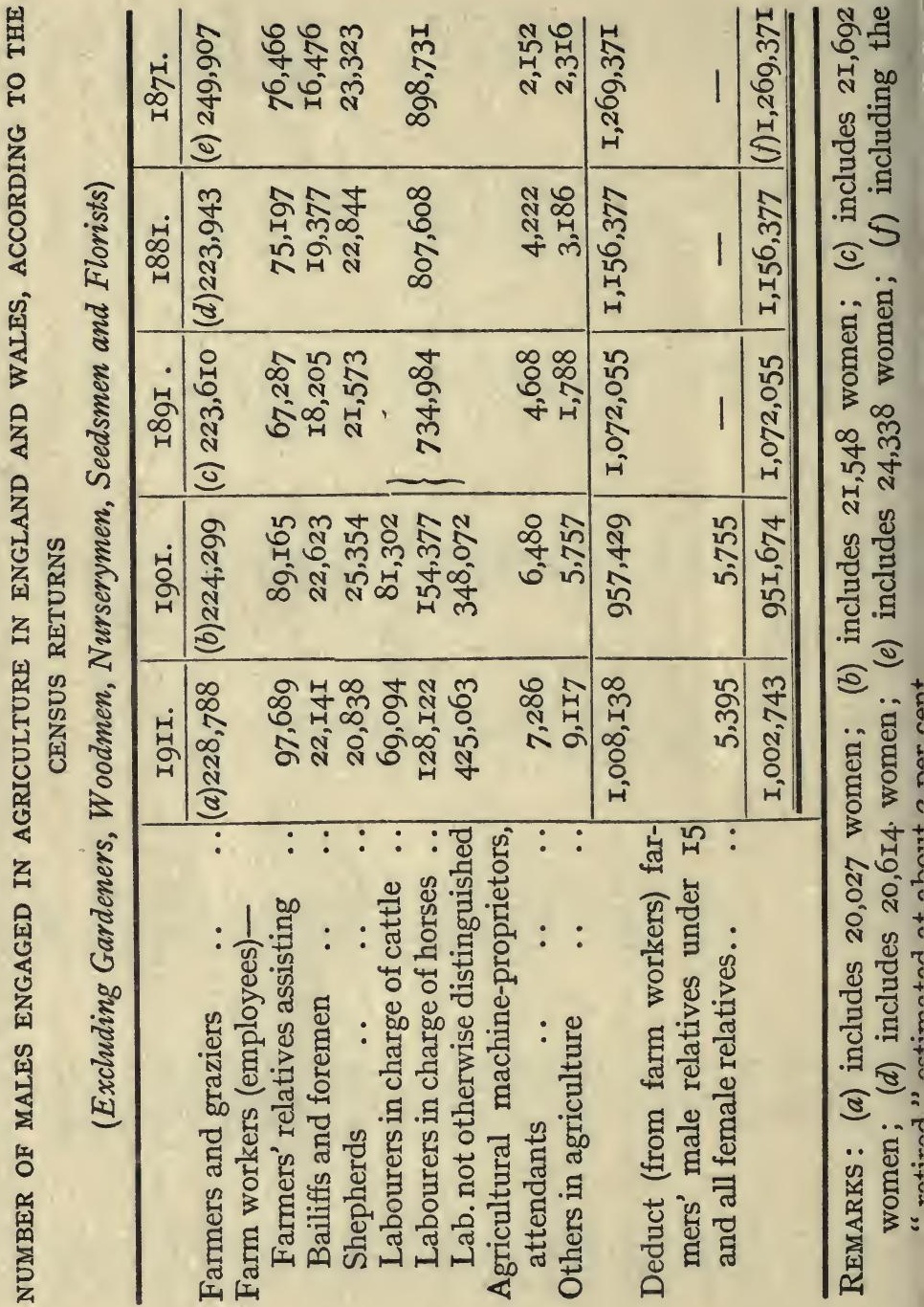




\section{APPENDICES}

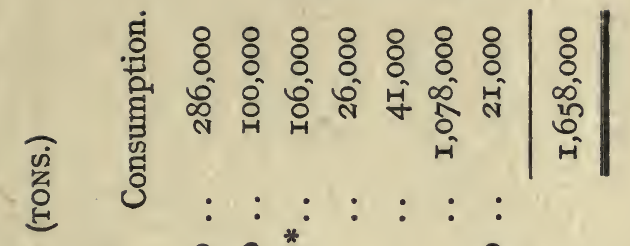

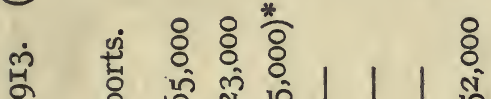

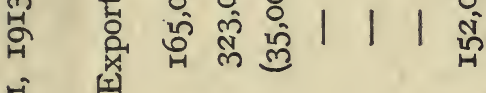

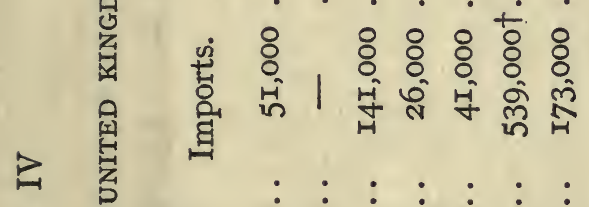

$:::::::$

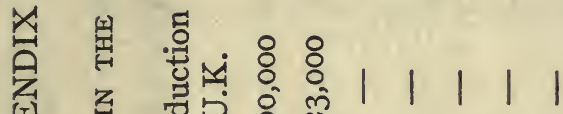

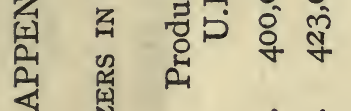

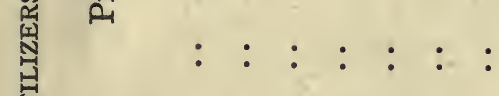

봉

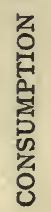

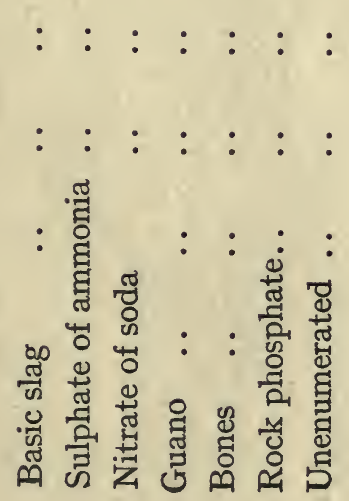

일

융 త్ర

ले के

它 总

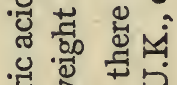

- 렬

록 可兘

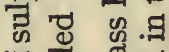

능 듬

능 이 त्

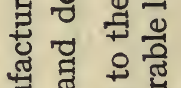

를 ๘

茜 坖

냉 क्ति क्षि

대 ․ㅡㄹ

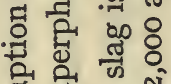

है है ज ले

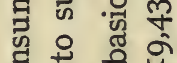

응. 봉

चु ఫ्रु

엄

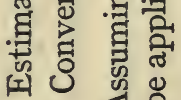

ㄷํ + 巡 
GARDEN CITY PRESS LIMITED, PRINTERS, LETCHWORTH, ENGLAND. 



\section{UNIVERSITY OF CALIFORNIA LIBRARY}

BERKELEY

Return to desk from which borrowed.

This book is DUE on the last date stamped below.

\section{NOV 281947}


$\frac{9 k 5}{125}, a$

\section{YB 19360}

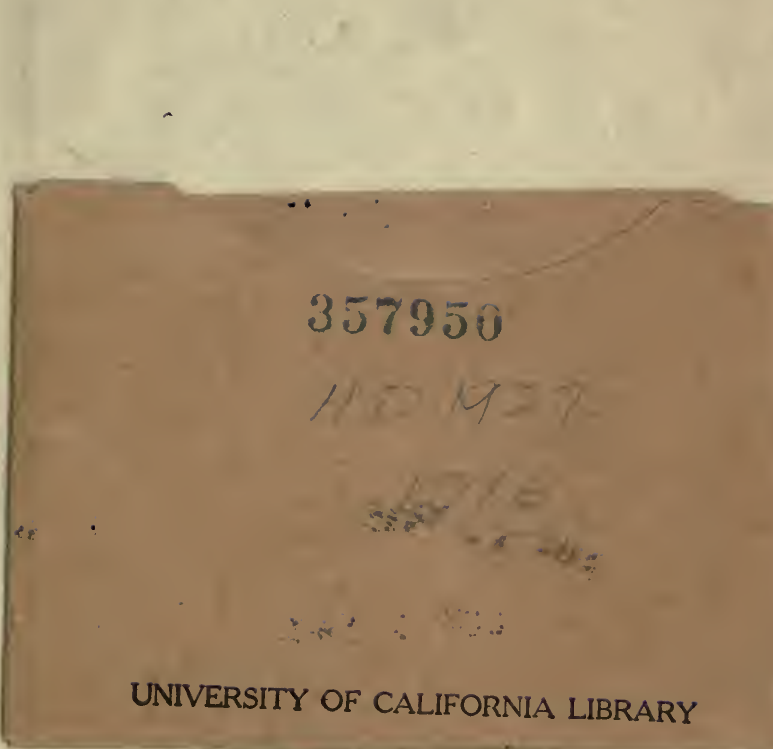

i.

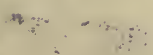




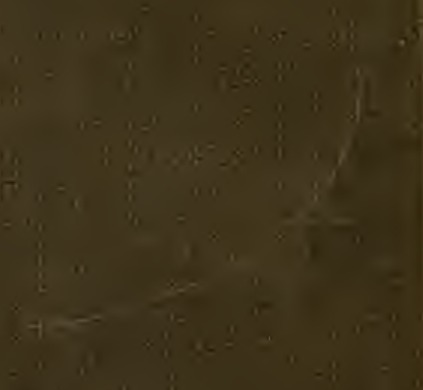

tong

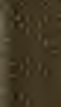

$50 \times 4$

2.9.

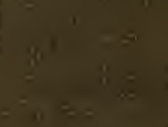

3

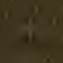

x-

7.
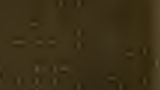